\title{
How can realism be utilised in an understanding of the United States/New Zealand relationship over nuclear policy?
}

\author{
By \\ Angela Fitzsimons \\ A thesis submitted in partial fulfilment of the requirements for the \\ Masters of International Relations (MIR) degree \\ School of History, Philosophy, Political Science and International \\ Relations
}

Victoria University of Wellington 2013 


\section{Abstract}

This thesis examines the decision making process of the United States and New Zealand on the nuclear policy issue through the lens of realism and analyses the effect of realism on the ANZUS alliance. Broader questions associated with alliances, national interest, changing priorities and limits on the use of power are also treated.

A single case study of the United States/ New Zealand security relationship as embodied in the ANZUS treaty will be used to evaluate the utility of realism in understanding the decision making process that led to the declaration by the United States that the treaty was in abeyance.

Five significant findings emerged: firstly both New Zealand and the United States used realism in the decision making process based on national interest, Secondly; diverging national interests over the nuclear issue made the ANZUS treaty untenable. Thirdly, ethical and cultural aspects of the relationship between the two states limited the application of classical realism to understanding the bond. Fourthly, normative theory accommodates realist theory on the behaviour of states in the international environment. Finally, continued engagement between the United States and New Zealand and evolved circumstances provided the means to revitalise a changed security relationship. 
How can realism be utilised in an understanding of the United States/ New Zealand relationship over nuclear issues?

\section{Table of contents}

CHAPTER 1: INTRODUCTION 4

1 Brief Background 4

$2 \quad$ Theory and Methodology 10

$\begin{array}{ll}\text { A Realism } & 11\end{array}$

B Methodology 19

$3 \quad$ Background to nuclear policy 20

Background to anti-nuclear policy in the South Pacific 24

$\begin{array}{ll}\text { A ANZUS } & 25\end{array}$

CHAPTER 2: THE NEW ZELAND AND UNITED STATES POSITION 27

1 The Anti-nuclear movement in New Zealand 28

A Environment $\quad 29$

B Viet Nam $\quad 35$

$\begin{array}{ll}\text { C Changing Strategic Alliances } & 37\end{array}$

D Regional Aspirations $\quad 38$

E Origins of anti-nuclear attitude $\quad 41$

F Geographic location 44

$2 \quad$ United States position $\quad 52$

A The Cold War Influence $\quad 53$

B The Nuclear Issue in the United States 55

C The South Pacific $\quad 57$

D Soviet Aspirations in the Pacific 58

E Nuclear non-proliferation $\quad 61$

CHAPTER 3: UNITED STATES POSITION ON ANZUS AND NEW ZEALAND'S RESPONSE

1 American reaction $\quad 65$

$\begin{array}{ll}\text { A No economic sanctions } & 67\end{array}$

B Realism in the United States response $\quad 71$

C The influence of norms $\quad 73$

2 New Zealand response to the United States action 75

$\begin{array}{ll}\text { A Focus on the Pacific } & 78\end{array}$

$\begin{array}{ll}\text { B Military engagement } & 79\end{array}$

CHAPTER 4: CONCLUSIONS

1 Future impacts $\quad 89$

$\begin{array}{lll}2 & \text { Future research } & 90\end{array}$

$\begin{array}{ll}\text { BIBLIOGRAPHY } & 92\end{array}$ 


\section{INTRODUCTION}

The aim of this thesis is: to examine the decision making process of the United States and New Zealand through the lens of realism and to analyse the effect of realism on the ANZUS alliance. When referring to nuclear issues in this thesis I am referring to the presence of nuclear weapons, nuclear powered and nuclear propelled military platforms. This is done in order to better understand the forces which influenced both the public opinion and the government policy decisions related to the nuclear issue. As it is now twenty-six years since the Australia, New Zealand, United States (ANZUS) treaty issue affected the previously close security relationship between the United States and New Zealand, it is timely to compare the drivers that led to the differing views on nuclear issues and to draw some conclusions on the ways that the two states now interact. This thesis addresses broader questions associated with alliances, strategic interest, changing priorities and limits on the use of power, which are issues that remain pertinent today. Moreover, the tensions and history of this issue help to better contextualize an understanding of the current United States and New Zealand military cooperation in Afghanistan. This thesis will evaluate the utility of realism in understanding the decision making process by both states and the limits of realism in terms of understanding motivations and a complex alliance relationship such as ANZUS. 
To set the scene succinctly ${ }^{2}$ : New Zealand and the United States had been traditional allies in both World Wars as well as allies in Korea and Vietnam. The relationship that binds the two English speaking nations together is founded on common principles, similar history in terms of becoming independent nations, similar liberal democratic political and economic systems and shared values and respect for free trade and global institutions. Given this common heritage the question must be posed as to why the nuclear issue between the late 1970s until 1985 provided such a cleavage in the overall well established relationship. ANZUS was the treaty signed between the United States, New Zealand and Australia that provided the only formal security between a major power and the two distant allies. It fell into abeyance in 1985 when New Zealand proposed excluding nuclear capable ships from the alliance obligations and the United States declined to accept negotiation on nuclear ship visits, a previously accepted aspect of the military relationship. This thesis will examine the factors that influenced the decision making process in both the United States and New Zealand; these factors include geographical location, the Cold War and the place in the international community through the lens of realism in order to better understand the forces which influenced the public opinion and the government policy decisions leading to a difference on alliance responsibilities and the nuclear issue. The argument will be centred on using the theory of realism to look at the reasons both nations initially came into the ANZUS alliance and what forces were at work on the international and domestic fronts. Nuclear policy became the point of tension between the two

2 A more extensive background is provided in the next section. 
states because of differing perspectives on the benefits of nuclear weapons. Two of the major factors lie in the physical place in the world in terms of geography and power and the completely different perspectives developed in both countries as a result of one being the western leader in the Cold War and the other being only peripherally involved.

The theory of classical realism with Morgenthau as the prime source has been chosen to examine the relationship for three reasons. First there is an obvious difference between the United States and New Zealand in terms of size. Because of the difference in size of economies, military capability and international influence, power is an ingredient in the relationship. A second reason realism is utilized is because although realism is a theory that has interesting perspectives for situations leading to war it is also worth examining in light of military alliances such as ANZUS because of the divergence of different national interests. Because of the differing global perspectives the structure of the ANZUS alliance constrained both sides in fulfilling the self-interest that each nation required for its place in the world. A third reason that realism has been used to frame this analysis is because of the Cold War context that framed the United States and New Zealand relationship.

Even though both nations were long-term allies the world had changed and New Zealand was not as intimately involved in the Cold War, as was the United States, although the ramifications of any conflict undoubtedly affected New Zealand. The divergence in interests came to a head over the nuclear issue and the perspectives of obligation and risk from the two parties are examined in this thesis. The Cold War ended with the United States and its allies prevailing without 
resorting to war. Realism is relevant because the maintenance of a coalition of nations and their combined military power and influence; contributed to the loading of the balance of power equation in favour of the West in terms of the range of democratic nations.

The broader objective of this thesis is to explore how realism can be utilised in an understanding of the United States/ New Zealand relationship over nuclear policy. My argument will be that only certain aspects of realism are applicable to United States nuclear policy decisions and that there was tension between balance of power politics and New Zealand's desire to exert its sovereignty. The consequences of the changed relationship forced New Zealand to interact more independently in the global arena and over time the acuity of the nuclear issue began to soften and become less relevant. Both nations now have a more cordial relationship although certain issues such as the visit of United States navy ship have yet to be navigated through. This reality raises questions as to the purity of decision-making based on realism and the applicability of realism to the New Zealand/ United States relationship. Additionally the relevance of the nuclear issue and the ANZUS alliance to the 2011 relationship is evaluated. The thesis will be structured to in four chapters; Chapter One will introduce the thesis, cover theory and methodology and the background. Chapter Two will cover the United States and New Zealand positions on the nuclear issue and analyse these from a perspective of realism. Chapter Three will analyse the United States decision on ANZUS and New Zealand's response and identify how realism can be applied to the decision making process. Finally Chapter Four will conclude and discuss the future impact and possible future research. 
The role of the United States in the South Pacific region will be covered briefly from an historical point of view followed by an exploration of the nuclear issue from the point of view of the nations present. Then the major part of the thesis will be organised to cover the circumstances and events in both New Zealand and United States with regards to the developing opposing positions on the nuclear issue. From the New Zealand perspective the reasons for the development of the antinuclear movement in terms of New Zealand's regional leadership aspirations to represent and use its power to influence world politics will be examined to understand how power effected the genesis and evolution of antinuclear thought within the nation. The second part of this chapter includes a discussion of the United States position on nuclear policy with an emphasis on the ways that size, commitments, and international roles impacted their perspective. An analysis of the decision made by the United States will be done using realism to understand the policy objectives. The United States response can be understood in terms of its position as the leader of the West in the Cold War, the owner of the largest Western military force, with its requirements to be able to project power to a range of locations, as well as the lead nation in a coalition of other non-NATO countries where the nuclear issue was sensitive. Chapter three will focus on the period after the rupture of ANZUS had occurred and split into two sections to examine the relationship from both the New Zealand and United States' perspective. The United States position can be explained by the need to maintain its power as well as to clearly be consistent with New Zealand in response to their decision to deviate from ANZUS so as to discourage any other nation from taking a similar stand. However other aspects of the relationship remained untouched by 
the ANZUS disagreement. The reasons for the containment of the difference to the military and parts of the political relationship will be examined. This chapter contrasts the firm and consistent responses of the US to New Zealand with regard to the military aspects of their relationship to the seemingly more rational approach the United States took with trade and international relations. This chapter hypothesizes that this contrast can be attributed to the recognition that there was a need to maintain a relationship of some sort rather than completed isolating a former ally to the extent that the relationship was irrevocably damaged. Instead of New Zealand being a "wayward ally", the possibility of destroying any future relationship and pushing New Zealand to a place where allegiance to a different partner did not occur because alienation of this degree did not appeal. It was also not a rational choice by the United States to completely reject a longstanding multilayered relationship which could prove useful in the future. The question as to why a more moderate approach was taken by the United States comes from a careful consideration of the consequences and an acknowledgement of the message that would be sent internationally to other allies. The boundaries of toleration by the United States of the national aspirations by a small ally, that are incongruent with the larger partners national interest will also be analysed. Also examined in Chapter Three is New Zealand's role in the nuclear alliance. From the New Zealand point of view the reaction to the placing of ANZUS in abeyance seem more obvious. Initially there was a period of denial of the damage to the ANZUS relationship as the Government of the time attempted to maintain the alliance relationship but as the reality of the concreteness of the United States position became clear, it was necessary for New Zealand to adapt to the new situation of 
realpolitik. New Zealand public opinion was generally behind the Government position in face of the perceived intolerance of the United States position to punish New Zealand. The international acclaim received by New Zealand (Prime Minister Lange's Oxford Union debate on 1 March 1985) for daring to stand up against a superpower also fuelled the determination of New Zealanders to remain resistant to United States pressure.

The significance of looking back over the United States/New Zealand relationship over the nuclear issue and drawing conclusions on the how the past tensions have transformed into the 2011 relationship where New Zealand and the United States are fighting as allies in Afghanistan is important because there are lessons to be learned on the evolutionary nature of ally relationships and that seemingly intransigent issues can be minimised and worked through with gains to both sides.

\section{Theory and Methodology}

The main argument of this thesis is that the New Zealand/ United States relationship and in particular the decision-making process that led to policy divergence over the nuclear issue can be better understood through the application of Morgenthau's six principles of political realism. Realism has been chosen as the theoretical lens through which to New Zealand/United States relationship will be viewed because of the imbalanced size of the two parties, in that the United States had the potential to wield substantially greater military, economic and political power than New Zealand as well as the historical context in 
which the relationship matured to a treaty. Realism is the theory of choice because of the emphasis on power and in the case of the New Zealand/United States relationship power in the context of a traditional ally provides a twist to the application of classical realism. Morgenthau's six principles of political realism will be the foundation of the theory used because they provide a framework for assessing the decision-making process of both states on nuclear policy. These principles have been chosen to examine whether they help to answer the central research questions of this thesis. Not all of these principles hold relevance to these questions; therefore, the relevant principles will be applied while those with less application will be critiqued ${ }^{3}$. Principles two, three four and five will be applied to the United States-New Zealand relationship and principles one and six will be critiqued. The major debates in realism relating to my topic will be reviewed with an emphasis on the decision-making aspects by both the United States and New Zealand in their nuclear stances. The rationality behind each nations decisionmaking process will also be covered.

Realism

Realism is a useful theory to apply to the United States-New Zealand relationship because it touches one of the most pertinent issues that caused tension between the two nations: sovereignty. The preservation of sovereignty is an essential element of realism because, according to this theory it is what is nations prize as essential to survival and thus to national interest. Realism is also

3 The principles will be detailed below. 
useful in understanding the restraint that was used by the United States in dealing with New Zealand once the alliance relationship was in jeopardy. It aligns with some of the norms literature in the link between rationality and international norms of behaviour. Finnemore, a constructivist writer ${ }^{4}$ proposes that the rational decision-making process does not exist without being influenced by generally accepted modes of behaviour. According to literature on norms ${ }^{5}$ interests are shaped by norms and that these cannot be opposing. In order to ensure survival nations often ally themselves with more powerful states and in New Zealand's case the alliance with the United States through ANZUS.

In the second part of this section realism will be reviewed in terms of its applicability to the current relationship between the United States and New Zealand in particular because nuclear weapons are less relevant because of the end of the Cold War and the removal of the then threat of mutually assured destruction. In particular the change in policy by the major powers including the United States in relation to nuclear weapons is worthy of examining in light of realist theory because of the implications on the change in the balance of power. The remainder of the section will examine each of Morgenthau's six principles of political realism and apply them to the United-States- New Zealand relationship. Finally the methodology used in the thesis will be described.

Morgenthau's six principles of political realism will be used to examine the relationship between New Zealand and the United States with regards to the

\footnotetext{
${ }^{4}$ Martha Finnemore, “Norm culture and world politics,” International Organization, 50, (1996), : 325341. 5 Martha Finnemore, National Interests in International Society, (New York, Cornell University Press, 1996), 27.
} 
nuclear issue. These principles ${ }^{6}$ are summarised as follows: firstly that politics are governed by objective laws and that rational theory reflects these laws, secondly that interest is defined in terms of power and that political realism does have a normative element, but the rational thought process leading to foreign policy decisions which minimise risk and maximise benefit are valued by political realism. Thirdly the key concept of national interest defined, as power is not fixed in time but evolves with history so that a certain set of relationships will change over time. Fourthly political realism is aware of the significance of political action and any moral principles which influence political action been to be viewed objectively through the lenses of time and place. Prudence is valued by Morgenthau as the "supreme virtue in politics" 7 because it provides the opportunity to weigh the consequence of actions and thus to make a rational decision. Fifthly political realism rejects the notion of transferring national moral aspirations to the international arena. The sixth and final principle states the great difference between the political realist school and other schools because of the determination to maintain the autonomy of the political sphere and although there is an awareness of the existence of legal, moral and economic drivers, political realism does not allow them to influence a decision. Of these six principles, those particularly relevant to this case study are two, three, four and five and these will be examined in greater detail. This approach has been taken because principles two to five related to decision-making, the changing nature of national interest and the moral aspects of action all of which have particular relevance to the case study.

\footnotetext{
${ }^{6}$ Hans Morgenthau, Politics Among Nation,(New York: Alfred A. Knopf, 1966), 4-14.

7 Ibid, 10.
} 
Principles one and six will also be applied to the United States/New Zealand relationship and these will be critiqued as not being relevant and therefore not explored for the purpose of this study. These two principles are less relevant for alliance relationship analysis because they focus on the social roots of politics and the diversity of influences of the legal, moral and economic dimensions of politics.

Morgenthau's first principle of political realism delineates between objectivity and subjectivity in politics and promotes the desirability of separating facts from emotion and making rational foreign political decisions based on analysis including consideration of consequences ${ }^{8}$. In the later chapters of this study the influence of emotion by both sides on the debate over the nuclear issue will be exemplified.

Morgenthau's second principle of interest defined as power carefully warns against the danger of deducing motives and of linking ideological preferences from statesmen's policy decisions. ${ }^{9} \mathrm{He}$ also acknowledges the existence of subjectivity in the making of foreign policy because of the human nature. So while aspiring to a purely rational foreign policy there are inevitable times when the democratic process and personal preferences will influence a foreign policy decision. It would be useful to apply this principle to New Zealand and the United States in an examination of the difference of opinion over the interpretation of the ANZUS alliance. The alliance was signed at a time when the US was focussed on post World War Two reconstruction primarily in Europe and to a lesser extent in Korea and Japan and the benefits of signing the ANZUS alliance were in favour of New

\footnotetext{
8 Morgenthau, Politics Among Nations, 10.

${ }^{9}$ Ibid, 6.
} 
Zealand and Australia who both sought to align themselves more closely with their World War Two ally by seeking a security guarantee. From the United States point of view the interest of the alliance was an assurance of the cooperation and facilitation that both of nations would supply if a future threat situation in the Pacific Area ${ }^{10}$ warranted attention. There were expectations on the side of the Americans of what the signature of a treaty implied and in particular obligations of the smaller to the more powerful.

In terms of realism the decision to seek an alliance with the United States when the potential threat of Soviet or Sino intervention in the region was accepted as existential was rational. The risks to both countries were minimised and the benefits maximised because of the choice of the nations involved to increase their collective power by entering into an alliance. However as more nuclear weapons were produced and delivery methods refined and expanded the cost benefit analysis changed for the smaller states as the presence of nuclear weapons could attract retaliation. The interest of New Zealand demanded re-evaluation and balanced against consideration of alliance obligations. From the United States perspective the potential renegotiation of ANZUS to include limits on the normative aspects of the agreement also required re-examination. As the more powerful member of the alliance, this translated into the ability to dictate what modifications were acceptable. The interpretation suggested by New Zealand was that it wished to remain in the alliance but not accept nuclear ship visits. This proposal increased the benefits in that certain normative aspects of the treaty

10 "ANZUS Treaty," http://australianpolitics.com/topics/foreign-policy/anzus-treaty-text. 
were eliminated and minimised the risk of nuclear retaliation. Conceding to this proposal was a diminution of United States power and not acceptable because of the precedent this would set for other allies who may have wished to negotiate the same terms.

Morgenthau's third principle of national interest defined as power is relevant to a certain extent but one particular phrase that is relevant to the New Zealand position on ANZUS applies comfortably with this study. Morgenthau explicitly differentiates between how a realist believes the world can be transformed. He explicitly rejects the notion that transformation can occur by the juxtaposition of political reality with an abstract ideal. ${ }^{11}$ This idea is interesting if it is applied to the confrontation of United States power against the concept of nuclear free world. If Morgenthau's logic were applied then United States power rationally would prevail over a concept based on the "abstract ideal "of the nuclear free world espoused by a less powerful nation. This principle also refers to the strength of shared national interest and Thucydides' quote on unity of interests supports this "identity of interest is the surest of bonds whether between states or individuals." 12 But Morgenthau does not conclude that shared national interests are permanent. He is pragmatic in that his realism accepts that foreign policy is subject to context. Therefore, as explained in this thesis, growing anti-nuclear sentiment, which culminated in the 1980s in foreign policy rejecting nuclear weapons, has merit because without the presence of nuclear weapons New Zealand could attract retaliation. However the main point of Morgenthau's

\footnotetext{
11 Morgenthau, Politics Among Nations, 9.

12 Ibid, 8.
} 
principle is that transformation of the world can only occur when power and interest are applied to achieve any change. So following this principle according to Morgenthau the realisation of a nuclear free world can be achieved when a powerful nation works for this aim not because it is desired as an abstract aspiration or in utopia.

When the fourth principle, the awareness of the moral significance of political action is applied to decision making of the fourth Labour government in chapter two, it could be argued that Lange did not reflect significantly on the effects both military and economic of displeasing the United States in the matter of negotiating ANZUS obligations. This fourth principle is relevant because it places emphasis on the need to filter moral principles through current circumstances of time and place and that the objective of national survival must be the mainstay of political action. The timing of the institution of New Zealand's anti-nuclear policy, in terms of the Cold War from the United States perspective was not ideal and incurred considerable risk for the United States in terms of the potential. Moreover, it could be argued that the New Zealand government did not consider the survival of New Zealand both economically and militarily. Conversely the moral significance of stating a case against the presence of nuclear weapons had appeal in the domestic New Zealand environment and also internationally in Europe and Asia. It will be argued that either party because of a lack of communication did not exercise prudence and that the courses of actions embarked on by both had a measure of inevitability to them.

The fifth principle of transferring national aspirations to the international arena is particularly relevant to the position taken by Prime Minister David Lange 
once the anti-nuclear legislation had been passed into law. Morgenthau would have found this espousal of national principles unacceptable. This principle also is worthy of application to the initial proselytising by New Zealand of the antinuclear message to the Pacific Islands and wider in the world, according to Morgenthau this fits the transfer of national aspirations to the international arena. There is a balance here between the freedom of speech of a nation and respecting the policies of other nations. In the context of the United States/New Zealand relationship the boundaries of seeking and equilibrium and using Morgenthau's advice of moderation in policy ${ }^{13}$ were stretched. Realism is a relevant theory to examine the United States/New Zealand relationship because it provides a useful perspective on how differently both nations regarded the nuclear issue. Realism and the power derived from owning nuclear weapons were inextricably linked in United States policy while for New Zealand this equation did not apply being neither a powerful or nuclear nation. Realism provides useful insights into the United States decision-making process and also into the New Zealand response. Realism will be used throughout the study to view the process and points in the argument when irrational emotion plays a major role and realism cannot explain this action.

13 Morgenthau, Politics Among Nations, 11. 


\section{Methodology.}

This research will involve a single case study of the United States/New Zealand relationship related to the nuclear issue using qualitative research to assess their different positions and motivations. The purpose of this study is to use realism to assess the relationship between two countries by investigating how and why decisions were made that changed the relationship and ended an alliance. This will be done by research using documents and statements of senior political and military personalities involved at the time. These documents include academic research, press statements, newspaper articles from New Zealand newspapers, addresses by the United States Ambassador, documents released by the United States Information Service at the Embassy and New Zealand Government Defence documents. The type of case study approach that is used is 'miss-fitting' as defined by Moses and Knutsen ${ }^{14}$, which explore the limitations of a given theory by using falsification logic. The historical case study approach will be used and applied to a theory that does not fit the case study and thus finds flaws in the theory. The New Zealand/United States relationship on nuclear issues will be examined to find where realism has a limitation in understanding the dynamics of the treaty relationship. Following this model of research the purpose of this study is to apply realism to the single case study of the United States/New Zealand relationship with a view to determining if the theory can help illustrate the decision making processes behind the relationship. Furthermore, the research will

\footnotetext{
14 Jonathon W. Moses and Torbjorn L. Knutsen, Ways of Knowing, Competing Methodologies in Social Science and Political Research, (Hampshire; Palgrave Macmillan, 2007) 138.
} 
identify any potential that there are weaknesses in the theory through an analysis of the particular aspects of the theory that are not applicable and do not help to understand this particular case of alliances and decision-making. To this approach I will add my professional experience to provide the reason for the amount of information included in the thesis without citation. My career as an Army officer has spanned twenty-seven years including peacekeeping missions in Bosnia, Bougainville, East Timor and Afghanistan. My opportunities have also been working in the United Nations Headquarters, New York for three years in Canberra and Staff College in Paris. During this time I have read extensively about the nuclear issue and the issues of the South Pacific and have available the resources of the Defence library.

\section{Background to Nuclear Policy}

In this section I will cover the background to nuclear policy of both the United States and New Zealand in the geographic region of the South Pacific including the Pacific Island states and Australia from World War Two until 1975. The purpose of this section is to provide a perspective of the political atmosphere in the region in terms of the purpose and presence of external powers. Since World War Two the Pacific region had been considered by the United States as "their lake"15. Germany had been forced to abandon its territory in Samoa in World War One and the threat of expansionist Japan had been eliminated after World War Two. The United States had fought in the Pacific campaign in World War Two with

\footnotetext{
15 Stephen Hoadley and Jurgen Ruland, 'Asia Security Reassessed,' (Singapore, Institute of South East Asia Studies publications, 2006) 118.
} 
a residual presence in American Samoa, the Federated States of Micronesia, the Republic of the Marshall Islands and the Marianas Islands. The status of the Pacific Islands ranged from colonies or trust territories of the United States, France, the United Kingdom, Australia or New Zealand. Firmly anchored in the Western sphere of influence, the Pacific Island states gradually emerged from colonialism and sought to find their places in international society under the sometimes, benevolent tutelage of their former colonisers.

Following the end of World War Two the Pacific slipped from the former status of a major theatre of war to an international backwater with the focus of the Cold War on Europe. The Pacific Islands had experienced the presence of major powers with the deployment of military forces from the United States and Japan and had endured the destruction of the environment and the legacy of unexploded munitions littering the land and coastal strips of the islands such as Guadalcanal, Bougainville and Papua New Guinea. Islands occupied by the Japanese such as the Solomon Islands and Papua New Guinea experienced the privations and some inhabitants sided with the Allied forces by acting as coast watchers and assisting isolated combatants. The example of Bougainville is appropriate here where New Zealand soldiers survived after becoming separated through the care of the Bougainvilleans.

A negative experience of the implementation of power politics by external large states in the Pacific had occurred, but nevertheless evidence of the benefits from the presence especially of the US forces remained in the form of the construction of some airfields, roads and other infrastructure which although initially for military purposes were development gains. This tangible evidence of 
the wealth of the US was coupled with positive memories of the generosity of servicemen with food and clothing. As quantified by Dorrance ${ }^{16}$ the goodwill was depleted by the 1970s-1980s because of perceived indifference.

As nationalist sentiments grew in the fledgling Pacific nations the memories of the past dwindled as little interest was demonstrated by the United States in this region. The exceptions here are American Samoa and the trust territories of Marshall Islands, Federated States of Micronesia New Zealand, Australia and France, the former two through there geographical proximity and the later through the colonies of French Polynesia, New Caledonia, Wallis and Futuna. The presence of the United Kingdom in the region diminished as territorial possessions were granted independence. One of the remaining influences of three of the major powers remained in the form of nuclear testing. The United States carried out nuclear tests on Bikini and Eniwetok atolls on the Marshall Islands between 194648, the United Kingdom used Christmas Island and Australia for testing atomic and nuclear weapons in the 1950s and allowed the United States to use the Christmas Island site in 1962,17 and France carried out nuclear tests on Mururoa and Fangataufa atolls in French Polynesia until 1996. The choice of the South Pacific as a region where nuclear testing was done resonated with the small states as an example of a neo-colonial and dismissive attitude to their sovereign rights being ignored. The conduct of nuclear tests did not immediately come to the surface as an issue causing tension between the region and the large powers but the activity

\footnotetext{
${ }^{16}$ John C. Dorrance, Ramesh Thakur, Jusuf Wanandi, L.R. Vasey, Robert L. Pfaltzgraff, Jr, The South Pacific, Emerging Security Issues and US Policy, (Virginia, Brasseys (US) Inc, 1990), vii. 17 Ibid, 28.
} 
sensitised island nations. This sensitivity was evidenced in the disparity of wealth, quality of life and influence between the two groups.

The prolonged duration of France's nuclear testing programme, after the United States and United Kingdom had ceased both atmospheric and underground tests exacerbated the sensitivity. The stance of New Zealand and Australia in supporting the growing movement against French nuclear testing, strengthened resistance on environmental grounds and enhanced the global visibility of these issues through lobbying at the United Nations. New Zealand had taken the step of bringing France to the International Court on the subject of nuclear testing and also of deploying navy ships to French Polynesia to protest the ongoing testing. The other linked area is that of the storage and dumping of nuclear waste in the region. Poor nations were attracted by the prospect of gaining supplementary cash income and not fully informed of the health dangers of living beside nuclear waste were vulnerable to suggestions and some accepted delivery. Branch cites the President of the Marshall Islands offering Japan the use of Bikini atoll for the storage of nuclear waste ${ }^{18}$. This issue provided further evidence to the South Pacific states of their utility to powerful nations at the expense of weakly protected national interest.

To summarise, an initial honeymoon period of good will existed by South Pacific states towards the presence of powerful nations in the region but this was gradually eroded, as the region was perceived as lacking in global relevance. Coupled with this was a growing consciousness of vulnerability to large powers

\footnotetext{
18 James B. Branch, "The Waste Bin: Nuclear Waste Dumping and Storage in the Pacific", Ambio, Vol 13, No. 5/6, (1984), 327-330.
} 
that used the region as a testing ground for nuclear and atomic weapons as well as a storage area for contaminated waste. The scene had been set for a more active approach to the protection of the regional environment from the damage of major powers usage.

Background to Anti-nuclear policy in the South Pacific

Two nuclear free zone treaties preceded the South Pacific Nuclear Free Zone; they are the Antarctic Treaty signed in 1959 and the Latin American Treaty of Tlatelolco signed in 1967. The Latin American treaty was entitled the Treaty for the Prohibition of nuclear weapons in Latin America and the signatories undertook not to possess, test or use nuclear weapons or to allow storage or stationing in their territory. ${ }^{19}$ A UN panel of experts explored the concept of nuclear free zones and a list of objectives was tabled which provided the basis for the South Pacific treaty. ${ }^{20}$ The decision to take this option was an interesting collective approach by a group of small states including some closely allied to the United States through the ANZUS treaty to make a stand on the issue of nuclear weapons in the region. Leadership of the group to suggest the treaty came from Australia and New Zealand the opportunity to discuss the proposed treaty occurred at the South Pacific Forum in July 1975. This organisation represents the Pacific Island States with New Zealand and Australia having observer status. The South Pacific Forum is important for the island states because it gave them an opportunity to develop regional policy and the collective power of the members had more impact on

\footnotetext{
19 Peter Glebeek, 'The South Pacific Nuclear Free Zone Treaty, A Lost Battle against the Superpowers?' Working Paper Series 73, 1990, 10.

20 Ibid, 12.
} 
external states than would have individual lobbying. The Forum is a vehicle through which island nations expressed their newly independent identity and provided a mechanism for states to present views to the larger neighbours of New Zealand and Australia.

\section{ANZUS}

The ANZUS Treaty was not the idea of the United States but was sought by Australia and New Zealand in the 1950s as a measure of security to balance the diminishing of British power to be able to offer protection to the Commonwealth. ${ }^{21}$ This treaty was less complex than NATO as it did not have a standing military commitment and was a relatively low maintenance alliance with its annual ANZUS council meetings where Ministers of Foreign Affairs met and discussed a wide range of military and political issues relevant to the region as identified by Secretary of Defence Denis McLean. ${ }^{22}$ It was an economical way for the United States to maintain a security relationship and military links with two far away allies and provided a venue for New Zealand and Australia to participated in an intimate dialogue when the United States. For the United States the perspective of like minded allies was received. One of the advantages to the United States of the ANZUS treaty was that it was part of the network of global alliances including regionally the Japanese Peace Treaty, the United States Japan Peace Treaty and the United States Philippines Peace Treaty ${ }^{23}$ which provided an interlocking set of

\footnotetext{
${ }^{21}$ Ramesh Thakur, In Defence of New Zealand, Foreign Policy Choices in the Nuclear Age, (Boulder Colorado and London: Westview Press, 1984), 34-38.

22 "ANZUS allows blunt dialogue with the US," The Evening Post, June 20 1984, 5

${ }^{23}$ Ramesh Thakur, In Defence of New Zealand Foreign Policy Choices in the Nuclear Age, 42.
} 
alliances that allowed US bases and port visits. The main focus of these treaties is the northern Pacific but because of Soviet economic and military interest the South Pacific could not be ignored and was covered by ANZUS. However the United States identified Australia and New Zealand as having responsibilities in the region: "We look to our ANZUS allies to continue their contribution to the South Pacific, South East Asia and the Indian Ocean." 24 This statement declares that the United States required allies to share the burden of containing the Soviet Union and that there was an expectation of contribution.

${ }^{24}$ Caspar Weinberger, “Department of Defence Annual Report to the Congress,” 1985, 43. 


\section{CHAPTER TWO: THE NEW ZEALAND AND UNITED STATES POSTIONS}

The central question of this chapter: how did divergent nuclear positions develop in the two case countries and what international events influenced the two nuclear positions. Using realism to frame this question will be divided into two parts that will address the New Zealand and United States positions in order to examine how the differing perspectives on nuclear policy developed. In the first part of this chapter the New Zealand position on nuclear policy will be outlined and analysed. This section addresses the following question: What then was the catalyst for the genesis of anti-nuclear sentiment in New Zealand? In this section I will argue that there are a combination of factors that led the general population of New Zealand to conclude that all things nuclear are dangerous. Specifically this chapter will highlight four specific reasons for the unique New Zealand position on nuclear capability. In the second part of the chapter the United States position on nuclear policy will be outlined and analysed. This section addresses the following question: What was the global situation that led the United States to its policy of intolerance to New Zealand's anti-nuclear choice? I will argue that the tension between Soviet expansionism and the constraint of anti-nuclear actions influenced the decision. Specifically this second part will cover the threat of communism, the nuclear issue, Soviet ambitions and aspirations globally and in the Pacific and the limitations placed on the United States. 


\section{The Anti-Nuclear Movement in New Zealand}

This section identifies four central factors influencing the New Zealand Government's policy decisions related to nuclear issues. Each of these factors will be examined in detail later in the chapter. The first of these factors is the environment. One of the main drivers for the growth of the anti-nuclear movement in New Zealand is the influence of environmental issues. A second factor for New Zealand a lingering anti-Americanism, which had its roots in the New Zealand contribution to the Vietnam War. The third factor that had an impact on the nuclear policy is the strategic alignment. New Zealand was far from Europe and theoretically distant from the prospect of nuclear confrontation as well as ideologically detached from nuclear weapons. This factor is linked to environmentalism and the establishment of a New Zealand identity which also links back to the physical place in the world as part of the South Pacific. New Zealand has constitutional responsibilities for other Pacific Island states (Niue, Cook Islands, Tokelau). As well it has a strong cultural identification with Polynesia through Maori ethnic ties as well as the presence of other Pacific Island communities from Tonga, Samoa and those states already mentioned. Because of these ongoing relationships, New Zealand took the role of spokesperson for these nations.

Finally there is a fourth factor related to a changing regional aspirations linked to the issues of nuclear proliferation and competition between the superpowers. The combination of these matters had the potential to result in nuclear war, a circumstance which had global effects. New Zealand was powerless to influence the decision to initiate a nuclear war but would be share the 
consequences. Government security policy was firmly committed to ANZUS, however as the generation of New Zealanders who had memories of World War Two started to fade from politics, the younger generation of politicians desired a more independent path linked with the growing sense of a separate New Zealand identity. Each of the reasons for the position adopted by New Zealand will be related back to realism using the framework of Morgenthau's six principles of political realism to shed light on the reasons for each position.

Environment

The concern by Pacific Island countries for the potential damage to the environment through the presence of nuclear weapons was founded in the practise of external powers testing nuclear weapons in the South Pacific. There was concern that nuclear testing would contaminate the islands and that an accident involving a nuclear weapon would also have the same effect. Thakur states the South Pacific States had been made sensitive ${ }^{25}$ to the nuclear issue by the United States conducting nuclear tests on Eniwetok and Bikini atolls, which are part of the United States Marshall Islands between $1946-58^{26}$ as well as the presence of aircraft carrying nuclear weapons based in the Northern Marianas Islands. South Pacific states were aware of the unwanted presence of nuclear testing and weapons that accompanied the major powers. Great Britain had also carried out atmospheric nuclear tests on Christmas Island and on the Australian mainland in the 1950s, and had permitted the United States use of Christmas Island to conduct

\footnotetext{
${ }^{25}$ Dorraance, Thakur, Wanandi, Vasey, Pfaltzgraff, The South Pacific Emerging Security Issues and U.S. Foreign Policy, 28

26 Ibid, 30.
} 
nuclear tests in $1962^{27}$. The longest-term user of the Pacific as a venue for nuclear tests is France, which began nuclear testing on Muruora atoll in French Polynesia, after newly independent Algeria forced France to find another venue. Between 1966 until 1974 France conducted 50 atmospheric tests ${ }^{28}$ and continued underground nuclear testing until 1991 with a further 150 tests. President Chirac misjudged the appetite for further nuclear tests and in 1995; the unfortunately timed tests recommenced in the year of the $50^{\text {th }}$ anniversary of the explosion of atomic weapons in Nagasaki and Hiroshima ${ }^{29}$. The sensitivity of Japan to nuclear issues becomes relevant in the second part of this chapter when the US position is expounded.

For Pacific Island states this pattern of these three nuclear states using the region as a venue to test weapons systems impinged on their sovereignty and national interest. Because of the disparity of size and lack of economic and military power in realist terms, Pacific Island countries were in a vulnerable position in terms of options open to persuade the nuclear powers of the legitimacy of their point of view. France had already faced the full brunt of regional opinion on nuclear testing when New Zealand and Australia separately brought cases against France to the International Court of Justice in $1973^{30}$. New Zealand's case was based on an accusation that fallout from the tests had caused pollution to

\footnotetext{
${ }^{27}$ Dorraance, Thakur, Wanandi, Vasey, Pfaltzgraff, The South Pacific Emerging Security Issues and U.S. Foreign Policy, 28

${ }^{28}$ Ramesh Thakur, "The Last Bang before a Total Ban, French Nuclear Testing in the Pacific", International Journal 51,3 (1996) : 437

29 Ibid, 474.

30Don MacKay, "Nuclear Testing: New Zealand and the International Court of Justice", Fordham International Law Journal, 19,5, (1995), 1843,
} 
national territories and followed up the legal action by sending a frigate to French Polynesia to protest the continued nuclear testing. ${ }^{31}$

Apart from nuclear testing the other environmental issue was the disposal of chemical agent. The Johnston Atoll Chemical Agent Disposal System (JACADS) was developed in the Pacific by the United States without consultation ${ }^{32}$ and raised alarm in Hawaii as well as other states in the region. This action as well as attempts by other Western nations to use Pacific Island states to store chemical and nuclear waste including Japan, the United States and France ${ }^{33}$ fuelled the perception that external states had no appreciation of where national self-interest impinged on the environment of others. This attitude is summed up by the words of the Paulau Legislative Speaker to Japanese scientists: “you don't throw the seeds of a poisonous fruit in the yard of your neighbour." 34

Environmental concerns are linked to the self-interest of Pacific Island nations, including by extension Australia and New Zealand through geographical membership of the region. This is because the states all are food producers either for self-sustainment as is the case with the small Pacific Island states who rely on the ocean and land to provide food. Australia and in particular New Zealand rely on the production of quality, uncontaminated to food to sustain their economies. New Zealand's economy has traditionally derived a high percent of GDP from

\footnotetext{
31 Don MacKay, "Nuclear Testing: New Zealand and the International Court of Justice," 1843

32 Richard Baker, The ANZUS States and Their Region, Regional Policies of Australia, New Zealand, United States.(Westport Connecticut, Praeger Publishers, 1994) 115

33 James B. Branch, "The Waste Bin: Nuclear Waste Dumping and Storage in the Pacific," Ambio, 13,5/6 (1984) 327-328. Branch cites evidence of France and the US dumping nuclear waste and the intentions of Japan and the US to dump drums of nuclear waste in Pacific locations. The London Dumping Convention provided a mechanism that the South Pacific Forum championed for the pacific region and collectively applied pressure to prevent nuclear waste being dumped in the Pacific.

34 Ibid, 330.
} 
export earnings gained from food production. The experience of the Chernobyl nuclear power plant accident in 1986 is a recent example that demonstrated the international market's demand that food is produced in a clean environment and the proof of this was evident when potentially contaminated beef and lamb from neighbouring European countries was declined in favour of New Zealand products. Prior to this the link between nuclear contamination and food produced in such an environment was acknowledged in Bikini atoll. The US stopped resettlement of former inhabitants after a radiological survey identified ${ }^{35}$ in 1980 and 1982 that the most likely way humans would ingest radioactive matter was through consuming locally cultivated food. The depth of feeling in New Zealand over the environmental consequences of nuclear pollution had been evident in national opinion and reflected in the policy of both major parties, care for the environment was part of the psyche of New Zealanders.

Anti-nuclear policy as a moral principle, as described in Morgenthau's fourth principle of political realism is applicable in this case where New Zealand's morale principle influenced the decision to take France to the International Court Justice. This political action was further emphasised by the concrete action of sending of HMNZS Wellington, a Minister and a group of media into the exclusion zone around the nuclear testing site of Mururora in French Polynesia. The international impact of this action provided a means of influencing world opinion. Morgenthau would have considered extension of the moral principle of antinuclear sentiment as a course of action as not compliant with his rational approach

\footnotetext{
35“ IAEA, Conditions at Bikini Atoll", last modified 5 February 2013 http://wwwns.iaea.org/appraisals/bikini-atoll.asp
} 
to decision making and imprudent because the weighing of the consequences through the perspective of time and place had not occurred. This means that the risk to the health of the crew and media had not been sufficiently valued against the internationalisation of the anti-nuclear cause. Diplomatic channels had not produced a satisfactory response from France and the decision to reopen the case against France in the ICJ in $1995^{36}$ can be ascribed to frustration. In taking a stance against a nuclear state over nuclear testing, New Zealand had begun to move down an independent policy path that would come into conflict with treaty obligations to the United States.

Morgenthau's fifth principle of political realism, in which he rejects the notion of transferring moral aspirations to the international arena had also been ignored by the action of Prime Minister Norman Kirk's Labour Government, who had deliberately chosen with the approval of the New Zealand parliament to internationalise anti-nuclear policy. This step was to take France to the International Court of Justice when protest by the Government was not heeded. There is realist aspect to the decision to internationalise the issue because of disproportionate size of the power of France and New Zealand in the South Pacific. New Zealand did not have sufficient power to stop France carrying out nuclear tests and the NATO relationship between France and the United States marginalised any influence the ANZUS partner could have used.

The establishing of an independent identity and reaffirming New Zealand's sovereignty are also factors, which contributed towards the position on nuclear

${ }^{36}$ Ramesh Thakur, “The Last Bang before a Total Ban: French Nuclear Testing in the Pacific," 481. 
weapons. The transformation from a Commonwealth country with a strong association with the United Kingdom to a state with an alliance with the United States, a close relationship with Australia, ties with ASEAN countries and security responsibilities for dependent small island states defines New Zealand's position as one of growing confidence. New Zealand's Defence White Papers have consistently defined security in terms ANZUS prior to the rift in the relationship to the extent of placing the treaty with Australia and the United States at the centre of national security. ${ }^{37}$

During the Cold War New Zealand's security interests aligned with the Western allies namely Britain and the EEC and New Zealand comfortably fitted into the Western balance of power. The Soviet Union remained present in the region and the potential threat from an expanded presence as articulated in Gorbachev's Vladivostok speech in which Soviet interest in the Pacific was emphasised had the effect of making the presence of nuclear-armed ships in New Zealand less desirable. There is a strand of logic in this argument by denying the presence of United States nuclear weapons New Zealand logically diminished the likelihood of attracting a nuclear response from the Soviet Union. Extrapolating this stance further and enacting a policy of questioning the presence of nuclear weapons on board a navy ship partially does meet Morgenthau's first principle a foreign policy decision of minimising risk but it fails the second criteria of maximising benefit if the benefit is considered as the obligations of the ANZUS alliance.

\footnotetext{
37 “Defence Review 1983,” 7.
} 
The opposite side of this argument will be analysed in the second half of this chapter where the American position on Soviet intentions in the Pacific will be covered. This will support one of the central arguments, which is that the ANZUS alliance offered protection but also enhanced the power of the United States by containing the Soviet Union. Taking an anti-nuclear stance became part of New Zealand's identity.

Viet Nam

New Zealand contributed forces to the conflict in Viet Nam and this was done as part of the forward defence policy embraced at the time. This policy accepted the logic of deploying well forward of national territory in order to dissuade a potential adversary. The Viet Nam War became unpopular in New Zealand as certain elements of the public questioned the ethics of becoming involved in a distant conflict where the national interests of New Zealand were not necessarily served. Evidence of this was the anti-war protests of the 1970s which occurred in New Zealand cities. The influence of emotion on politics was visible in the anti-Viet Nam demonstrations within New Zealand and questioning of government policy to commit forces in pursuit of alliance responsibilities. The geographical isolation of New Zealand played into the questioning of the need to belong to an ANZUS and the consequences of military commitment to conflicts such as Viet Nam perceived as irrelevant to New Zealand's national interest. Morgenthau was critical of the United States intervention in Viet Nam as being contrary to national interest and he stated: "Intervene we must where our national 
interest requires and where our power gives us a chance to succeed." 38 He goes further to express the necessity to calculate the national interests and power at stake prior to any intervention and that if the United States followed this model it would intervene less frequently and more successfully. The logic applies equally to New Zealand and the Viet Nam war, although Morgenthau never covered this issue, however the decision to intervene as part of an alliance obligation further complicates the process because national interest is partially sublimated to the national interest of the more powerful alliance partner. The New Zealand public questioned this level of commitment because the implicit equating of New Zealand and United States national interest in Viet Nam is not easily explained. Thakur ${ }^{39}$ and independently Hoadley 40 identify the convergence of anti-Americanism with anti-nuclear consciousness as influences on New Zealand society. The deployment of military to Viet Nam to fight in what was perceived as an American war without any interest to New Zealand was exacerbated by the fact that Viet Nam was a trading partner at the time. The expeditionary nature of the conflict and the willingness of the New Zealand government to put New Zealand Defence Force personnel in harms way inflamed parts of the general population who linked the United States war machine directly with the nuclear capability. The logic behind this can be attributed to the common factor of the United States. Morgenthau's argument that the United States should have been involved in the Viet Nam war

\footnotetext{
${ }^{38}$ Hans Morgenthau, To intervene or not to intervene,"Foreign Affairs, 1967, 463

${ }^{39}$ Ramesh Thakur, In Defence of New Zealand, Foreign Policy Choices in the Nuclear Age, 30 ${ }^{40}$ Stephen Hoadley, "New Zealand United State Relations, friends no longer allies," New Zealand Institute of International Affairs (2000)
} 
applies equally to New Zealand because it was not in the national interest of either country.

\section{Changing Strategic Alliances}

New Zealand had been long attached to the United Kingdom through Commonwealth and trade links, however since the withdrawal of Britain from commitments east of Suez, New Zealand readjusted its strategic outlook to the United States to provide a security guarantee. New Zealand's defence policy had as its cornerstone the ANZUS alliance. Since the decision of Harold Wilson's government to withdraw British bases from east of Suez in $1968^{41}$ one alliance linking New Zealand and the United Kingdom that remains still is the Five Power Defence Agreement ${ }^{42}$. New Zealand's military experience has, with the exception of the New Zealand land wars always been as an long distance contributor to wars geographically distant from the state. The acceptance of the importance of forward defence and the habitual deployment of defence forces has been a tenet of military commitment.

New Zealand's identity apart from Britain was established symbolically through diplomatic representation in the United States, with the opening of the of first NZ Embassy in Washington in 1941. From the New Zealand perspective the establishment of a national identity has a powerful influence on policy decisions,

\footnotetext{
41 Matthew Jones, “A Decision Delayed: Britain's withdrawal from South East Asia Reconsidered, 1961-68," English Historical Review,117 (2003) 1

42 Five Power Defence Arrangement signed between New Zealand, Australia, United Kingdom, Malaysia and Singapore in 1971 to provide air defence for Singapore and Malaysia following the British withdrawal of forces from the region. The Arrangement remains active to the present day and involves the presence of military personnel from the partners in Malaysia as well as annual exercises and consultation between Defence Ministers.
} 
which culminated in the nuclear issue. The development of a New Zealand national identity had an element of rejection of the positions of allies in an attempt to define the nation as unique and different from others. The proximity of Australia plays into the New Zealand identity through an instinctive choice to create a separate identity from Australia, despite the irony of shared colonial experience and convergence of policy on the nuclear issue. Geographical isolation also is a factor in the creation of a national identity with a rejection of the problems confronting the United Kingdom and Europe including the Cold War. This resulted in an attraction to the United States whose identity as a new world country with similarities to New Zealand in terms of a fresh approach to international relations.

\section{Regional Aspirations}

The experience of conflict in South East Asia in both Malaya and Vietnam alongside the Britain and Australia in the first conflict and the United States and Australia in the second conflict had set the scene for acceptance of the concept of regional ties and the benefits and obligations provided by the ANZUS treaty. Membership of ANZUS and SEATO and the security relationship with the United States achieved through this treaty had an influence on the New Zealand government's decision to commit forces to the Viet Nam conflict. Initially the Government committed non-combatant unit but under pressure from the United States expanded the level of commitment to include combat units. ${ }^{43}$ The shared notion of defence against the communist threat and the need to defend against the

43 VietnamWar.govt.nz ,http://veitnamwar.govt.nz/resources, accessed 2/12/11 
domino effect of South East Asian countries falling under communist power was a driver in the decision to deploy forces. ANZUS was the major collective security agreement of New Zealand's defence policy and its foundation as is articulated in the Defence White Papers and in particular in the 1983 just prior to the nuclear issue becoming problematic.

Recognition of the benefits of collective security and the advantages for the smaller partner are spelt out "Membership of a collective security arrangement however permits a small country to integrate its military efforts into a larger more comprehensive response... ANZUS thus remains fundamental to our defence interests." 44 The review also stresses a focus on the South Pacific region where many states had achieved independence from previous colonial masters or had achieved a measure of self-determination. Implicit in the review is an understanding of the fragility of the new states and their vulnerability to interference and opposition of nuclear testing. 45 This focus fits with the growing identification by New Zealanders as inhabitants of the region and the responsibilities this entailed. Such responsibilities included representing the interests of smaller island nations in international forums and a leadership role on issues of regional concern such as nuclear testing. Part of the New Zealand identity is Polynesian combining the influence of its Maori population as well as immigrants from Pacific Island countries. This includes the special relationships which still endure with Niue, Cook Islands and Western Samoa allowing significant immigration to New Zealand. The ethic identity also plays into the interest of

\footnotetext{
44 “Defence Review 1983," 16

45 Ibid,12.
} 
Pacific Island countries in their relationship with land and in the language of New Zealand Maori, the notion of stewardship as the Tangta Whenua (people of the land) New Zealand developed a role among the micro states as the mouthpiece to air concerns which was accepted in the 1980s as benevolent.

The Pacific region had been neglected by the United States following the end of World War Two and the United Kingdom had mainly disengaged from their colonial interests. The interest manifest by major powers in the region was perceived as exploitative and attempts to use Pacific islands as the dumping ground for toxic waste and the pursuit of atmospheric nuclear tests by France were the reasons for large powers interest. Coupled with this is a perception that because New Zealand had never been invaded, the security provided by the isolation of geography could be a competitive advantage and a nuclear ally eroded this safety. Distance from major world conflicts, with the exception of Japanese threat during World War Two provided a sense of isolation, which a relationship with a nuclear power diminished. Evidence of the growing role as a regional leader is exemplified by the creation of the South Pacific Commission ${ }^{46}$ and the Pacific Island Forum. Both of these institutions provided mechanisms for regional countries to discuss matters of common interest and provided the microstates with a vehicle to consolidate their voices and influence.

The influential role played by New Zealand in these institutions contributed to the evolution of the national identity as a Pacific Island nation and provided

46 Roy E James, 'The South Pacific Commission', Pacific Affairs, Vol 20, No 2, 1947, 193-1 South Pacific Commission as a companion to the 1944 Canberra Pact to ensure common policy on the wellbeing and advancement of peoples in their territories, that Pacific states joined when independent 
New Zealand with an opportunity to pursue its national interest in contributing to the security of the South Pacific. The aim of New Zealand's national interest in this context is twofold: to promote a secure pro-Western South Pacific and to assist with economic development and preserve an export market ${ }^{47}$ for New Zealand and avoid the necessity to send forces to protect New Zealand trade opportunities as identified in the description of the defence perspectives in the Defence White Paper of 1983: “In New Zealand's case they (Defence policies) must reflect the facts of a small population inhabiting large islands in a vast ocean space and must take account of a relative lack of industrial self-sufficiency and a consequent high dependence on international trade across extended lines of communication." This description encapsulates the range of considerations to be factored into defining the New Zealand national interest.

\section{Origins of anti-nuclear attitudes}

The environmental and regional concerns of the Pacific Island countries coalesced in the launching of the proposal to establish a South Pacific Nuclear Free Zone (SPNFZ). This idea originated in Labour Party policy in the $1970 \mathrm{~s}^{48}$ and strengthened as a foreign policy including the prospect of banning ship visits, vocal opposition to French nuclear testing and support of the Indian Ocean Zone of Peace. It was not the Labour Party alone that had concerns with nuclear testing and the National government under Robert Muldoon had raised the issue

\footnotetext{
47 Thakur, In Defence of New Zealand Foreign Policy, 63

48 Ibid, 161.
} 
internationally ${ }^{49}$. In other Pacific Islands frustration was also growing at the obduracy of France in continuing the nuclear testing programme despite regional opposition.

Nuclear free zones had become popular following the successful signing of the Treaty of Tlatelolco, which established a nuclear weapons free zone in Latin America. SPNFZ was tabled by New Zealand at the South Pacific Forum in 1985 in Rarotonga and was primarily aimed at French nuclear testing. The decision by the Pacific Islands and Australia and New Zealand to conceive of the idea of a treaty was in frustration with the French intransigence to attempts to negotiate the nuclear testing programme. Collectively signing a formal instrument was an attempt to gain traction on the issue by combining the small amounts of power possessed by the states. The language of the treaty reflects the concern of Asia Pacific states of the future use of nuclear weapons ${ }^{50}$ in the region as had occurred in Nagasaki and Hiroshima. The treaty expands on the nuclear weapons issue to include articulated concern for the issues of nuclear testing and dumping of nuclear waste in the region.

SPNFZ consists of three protocols the first prohibits the manufacture, stationing and testing of nuclear explosive devices and aimed and was open to France, the United Kingdom and the United States. Protocol two invites signatories, the previous three states as well as China and the USSR not to use or threaten to use nuclear explosive devices against other parties to the treaty or territories within the SPNFZ. Protocol three, open to the same group invites the

\footnotetext{
49 Ibid 162.

50 Text of South Pacific Nuclear Free Zone Treaty, entered into force 11 December 1986
} 
signatories not to test any nuclear devices within the SPNFZ. The signature of this treaty was problematic to most nuclear states, although the USSR signed with some reservations in 1986 and China signed in $1987 . .^{51}$ The United States or France did not sign the treaty initially and the rationale for not signing will be covered in the second part of this chapter.

From a realist point of view the maximisation of power can be understood as the objective of the thirteen full members of the South Pacific Forum who signed the treaty in terms of cooperatively attempting to assert influence over their environment. The purpose of working together as a bloc of countries was to gain the attention of the US and of France on the seriousness of their attempts to end of nuclear testing. The concept of small states coordinating an anti-nuclear treaty in accordance with the United States non-proliferation goals is interesting if viewed from a realist point of view. Morgenthau's theory of realism supports this course of action as rational against the actions of a much larger power. The combination of many countries using international forums to influence through their collective power is more effective than a single voice. Also his view on interest defined as power fits with the aims of the Forum countries, whose common interest was aligned in order to achieve the goal of stopping nuclear testing.

However according to Morgenthau's seemingly cynical theory on the success of such a tactic, it would likely be that a group of small states aligning to persuade a more powerful state to change its position on nuclear weapons testing was futile. When national interests clash the more powerful state wins. Applying

\footnotetext{
${ }^{51}$ Dorrance, Thakur, Wanandi, Vasey, Pflatzgraff, The South Pacific Emerging Security Issues and US Foreign Policy, 30.
} 
power politics to the attempt by Pacific Island states to stop nuclear testing was an inevitable failure because of the disproportionate amounts of power in terms of military, economic and political. From the small states point of view and in particular New Zealand Morgenthau's second principle is relevant because the making of a foreign policy decision on the rational thought process that supporting the creation of the South Pacific Nuclear Free Zone minimises the risk of nuclear weapons and maximises the benefits by excluding activity of nuclear powers from an area far from their geographic mainland (although this point would be arguable to France as Pacific territories are considered part of France). Non- proliferation of nuclear weapons was a subject of interest to New Zealand because of the feeling of impotence that non-nuclear states experienced in the Cold War. The negotiation of non-proliferation treaties provided a vehicle for the involvement in decisionmaking and the championing of SPNFZ was New Zealand's contribution to this global cause. The failure of the United States and Soviet Union to make meaningful progress in the negotiation and implementation of the SALT and START agreements and the worsening of the relationship between the two superpowers exemplified the stalemate. As the relationship became tenser New Zealand was strengthening its anti-nuclear sentiment.

\section{Geographical Location}

Woven into all of the above factors is the reality of New Zealand's geographic isolation. The NATO/Soviet Union prime area of operation was Europe and although the possibility of nuclear war meant that New Zealand's geographic 
isolation would not protect it from nuclear fallout, the very fact of the isolation meant that New Zealand had an improved chance of survival.

New Zealand is also isolated and independent with respect to its energy needs. New Zealand's energy sustainment relies on other means (geothermal $(12 \%)^{52}$, hydro $(57.8 \%)$, gas and coal (31.65\%) electricity production) rather than nuclear power production. New Zealand with its relatively small population and small industrial complex has the luxury of not yet having to contemplate the development of nuclear energy capability. This situation provides an environment where the possibility of a nuclear accident is absent and the logical step to not embrace the presence of nuclear powered or armed warships follows understandably follows. However the number of visits to New Zealand ports of US ships during the period suggests that concern over a nuclear accident did not feature frequently as important enough to regulate for successive governments. United States Navy ships visited New Zealand ports regularly between 1960 and 1984 there were 148 ship visits, thirteen by nuclear propelled and vessels and aircraft carriers, four cruisers and five by attack submarines. ${ }^{53}$ Protests by peace groups against US warships occurred from $1976 .{ }^{54}$ These included attempts by peace flotillas to prevent US Navy ships from entering harbours. The protests against nuclear ships was by no means unique to New Zealand and carried while the ANZUS alliance remained in the background for both Labour and National governments. Protests groups such as the Campaign for Nuclear Disarmament and

\footnotetext{
52 Nationmaster NZ energy statistics http://www.nationmaster.com/country/nz-new-zealand/eneenergy

53 Hoadley, New Zealand United States Relations, friends no longer allies, 42

54 Ibid 43.
} 
Greenpeace ran petitions, carried out protest marches and sailed fleet of small private boats and yachts sometimes of up to 80 vessels sailed in reaction to the presence of nuclear ships visiting New Zealand ports.

The Labour opposition under Bill Rowling signalled its intention to ban nuclear ships in Washington ${ }^{55}$. This debate became a live issue in New Zealand society in academic circles with the input of Dr Desmond Ball from Australia, discussion by civil servants and the media and eventually an issue which became mainstream. In 1984 after a period of nine years of National government the Labour party came to power under the leadership of Prime Minister David Lange. Labour and National governments differed over the years in the emphasis placed on economic and associated defence alliances but in 1972, the year after New Zealand soldiers were withdrawn from Viet Nam, Prime Minister Norman Kirk from Labour indicated that he intended to follow a more independent foreign policy ${ }^{56}$. The theme of New Zealand politicians wishing to create an independent stance linked with sovereignty again appears particularly in the politics of the Labour party.

With a change of government in 1984 the themes of anti-nuclear thinking, anchored in environmental concerns from both sides of the political spectrum and shared by neighbouring Pacific Island state and Australia coalesced into a more focussed anti-nuclear stance articulated by a group of young Labour politicians. The Wellington Labour Party conference in 1983 proposed a remit that sought withdrawal from ANZUS and a policy of non-alignment. This proposal was one of

\footnotetext{
55 Editorial, "Reminder on ANZUS” The Dominion, April 23, 1979,

56 David J. Mc Craw, "New Zealand's Foreign Policy Under National and Labour Governments: Variations on the 'Small State' Theme?," 18.
} 
the more radical to come from the conference but indicates the depth of feeling on the nuclear issue from the party and an openness to accept the possibility of an isolationist policy for New Zealand.

“ That the Labour Party's policy be one of neutrality between the two major power blocs and that New Zealand's defence needs be catered for by regional South Pacific arrangements and that, as a consequence of New Zealand's removal from treaty ties with any nuclear power, our support for a nuclear-free Pacific and self-determination of Pacific peoples, New Zealand's prime interest be seen as our involvement in the evolution of the Pacific Basin." 57 The Wellington regional conference intentions were radical and not all were adopted but provide a useful insight into the intentions and flavour of the left wing elements within the Labour party. These elements would prove powerful in shaping the policy direction of the new government.

The major incident that polarised the difference of opinion between the United States and New Zealand was a proposed ship visit, the first following the new Labour government's term. The United States demonstrated sensitivity to the domestic anti-nuclear sentiments and proposed the USS Buchanan. This ship was, a conventional non-nuclear powered guided missile destroyer, of an older vintage which had previously visited New Zealand. As such, there was no increment in the level of technology and the ship was not nuclear-powered. The United States had previously indicated through the military the message of the government. Admiral Crowe, the commander-in-chief for the Pacific when questioned on Labour Party

57 Richard Long “Labour faces debate on Anzus remit," The Dominion, April 26, 1986, 8 . 
policy of requiring a declaration from visiting ships on the presence of nuclear arms replied: “ I don't foresee any change in my government's policy (of refusing to confirm or deny the presence on board of nuclear weapons)." 58 The same message was also signalled by Secretary of State Shultz in the press conference following the ANZUS Council meeting in Wellington in answer to the question on whether it is essential for ships to be allowed into member nation ports for the continuation of the treaty: "Of course. What kind of alliance would it be if the military forces of the countries involved are not able to be in contact with each other."59

Despite the language there was an intention to find a solution to the nuclear impasse throughout the public statements made, and an example of this was that Shultz alluded to stating of national positions, discussion, the need for patience and finding a resolution ${ }^{60}$. At this point disagreement was inevitable, as the two positions did not have much common ground. ANZUS implied responsibilities such as the hosting of visiting nuclear warships and from the point of view of the United States implicit in this was acceptance of its policy on neither confirming nor denying the presence of nuclear weapons.

The New Zealand government wished to negotiate the specific obligations of the treaty as the language of the instrument was general and did not spell out in detail any references to ship visits nuclear or otherwise. Nowhere in the text of the ANZUS treated is there a mention of nuclear ship visits. This intention to negotiate was the crux of the issue. In, realist language the probability of a small state

\footnotetext{
58 Anthony Hubbard, "Admiral backs ANZUS," The Dominion, April 13, 1984, 10. .

59 United States Information Service, "Transcript of Press Conference 33rd ANZUS Council Meeting," 3. 60 Ibid, 4.
} 
having the power to influence the policy of a larger state is slim. . New Zealand's position was clear and despite officials attempting to find a middle ground by proposing to send a less offensive ship, hence the choice of the USS Buchanan, the actions leading to a policy impasse had begun.

Once the request for the ship visit of the USS Buchanan had been placed with the New Zealand government and the neither confirm nor deny question posed, the consequences were inevitable. American reaction was swift but measured. This reaction will be examined in the following section. The reaction seemed to surprise the New Zealand government who had genuinely believed that negotiation of selected parts of ANZUS responsibilities was possible. The national newspaper at the time ran a headline stating: "America retaliates" 61 and went on "We deeply regret this decision to deny port access to a United States Navy ship contributing to the common defence of the Anzus alliance. As we indicated January 31 , the denial of port access is a matter of grave concern, which goes to the core of our mutual obligations as allies. Accordingly, we are considering the implications for our overall co-operation with New Zealand under Anzus, including the question of our participation in military exercises." ${ }^{2}$ The fact that the Labour government did not expect this response illustrates a communication problem between two close allies. This suggests that divergence of national interests by both sides had not been appreciated.

\footnotetext{
61 Anthony Hubbard and Bernard Lagan, "America Retaliates," The Dominion February 6, 1985, 1 62 "US Ready to discuss Anzus," The Dominion, February 6, 1985, 1.
} 
New Zealand's position can be critiqued by Morgenthau's second principle of political realism ${ }^{63}$ because it provides evidence that according to realism, a rational thought process had not occurred and that the consequences of the United States unwillingness to concede had not been considered. It was not rational to have ignored the possible course of action and consequences of the American decision and this exposed New Zealand's national interest. According to Morgenthau's theory good foreign policy maximises benefit and minimises risk ${ }^{64}$ what the David Lange Government had achieved was to risk the benefits of the ANZUS alliance and also other retaliatory action with potential to damage New Zealand's economic relationship with its ally as well the military benefits. Morgenthau's cost benefit analysis approach appears not to have been applied in that he identifies one of the reasons a nation will reject an alliance is when the burden of commitments outweighs the advantages ${ }^{65}$ and the value of prudence had also been ignored as well as the intrusion of emotion into the decision making process is evident.

Evidence from a poll commissioned by the government in 1986 provides an insight into of public opinion that did not support the visits of nuclear ships but paradoxically ANZUS membership was supported. The results of the poll by the Defence Committee of Enquiry provided evidence for the government of the popular support of its anti-nuclear stance. But the poll indicated opposition to nuclear weapons and nuclear weapons testing, a belief in the absence of a conventional military threat to New Zealand, support for alliances especially with

\footnotetext{
${ }_{63}^{63}$ Hans J Morgenthau, Politics Among Nations, The Struggle for Power and Peace, 5-8.

64 Ibid, 7.

65 Ibid, 175.
} 
Australia and the United States and strong support for non-military and peace keeping roles for the New Zealand Defence Force ${ }^{66}$. This dichotomy is interesting and is at the heart of political opinion in the Labour Party.

Throughout the debate, the differentiation between membership of ANZUS and observation of alliance obligations such as the permission to question the carriage of nuclear weapons conveys the essence of the problem. New Zealand's national interest was not served by the presence of nuclear powered or armed ships, conversely public opinion embraced the logic that the presence of nuclear armed ships increased the likelihood of attack by the Soviet Union. In summary there is not one main issue that led to the solidifying of the anti-nuclear policy in New Zealand, environmental concerns centred on French nuclear testing were the catalyst to the policy and the establishing of the New Zealand identity as separate from its traditional larger allies and also representative of other smaller Pacific Island states were contributing factors. Geographic isolation, anti-Americanism with roots in the Viet Nam experience, frustration with the lack of influence over the proliferation of nuclear weapons also contributed. The moral approach of the new Government fuelled and indebted to a more radical influence inside the Labour party also cornered the Government into taking steps in the alliance relationship with the United States. Morgenthau would have considered these steps imprudent and without due diligence to the consequences. In the next section of this chapter the position of the United States will be examined and

${ }^{66}$ Hoadley, New Zealand United States Relations, friends no longer allies 47 
realism applied to the decisions made.

\section{United States Position}

In the second part of this chapter I will firstly provide a brief background on the nuclear issues of the United States in order to understand the context of the ANZUS decision. Realism will be applied to the United States position to assist us in understanding the decision-making process leading to the policy tension. Here three specific factors are analysed including the influence of the Cold War, Soviet ambitions globally and presence in the South Pacific, implications of SPNFZ and other limitations placed on the United States. Finally, the contextual background of what the United States government was attempting to achieve globally will be examined through the lens of Morgenthau's realism.

The United States and New Zealand have long historical, cultural, economic and military ties and there are some similarities in the geographical context where both nations are separated from others (Europe and Australia) by significant bodies of water. ${ }^{67}$ As Morgenthau identified there are foreign policy consequences that flow from geography ${ }^{68}$ and in the case of the United States and New Zealand at some time in their histories, both states have been tempted by the attractions of isolationism for different reasons, in their foreign policy postures. The United States had been drawn into both World Wars less willingly than their European allies. However, after the Second World War, the pre-eminence of economic and military power changed the status into a superpower and leader of the Western

\footnotetext{
67Morgenthau, Politics Among Nations, The Struggle for Power and Peace, 106. 68 Ibid, 107.
} 
world. The United States led coalitions in the conflicts in Korea and in Viet Nam and confronted the threat of communism where it deemed necessary.

The Cold War Influence

In the 1980s Ronald Reagan was President served two terms in office. One of his major political challenges was the containment the Soviet Union, which since the end of World War Two had competed militarily with the United States in Europe where NATO stood poised against the Warsaw Pact forces. The Soviet Union also promoted the spread of its brand of communism throughout the world in an attempt to gain influence in other geographic areas to distract the United States from the European theatre and to constantly put pressure on less developed or other nations to change allegiance. The United States had invested considerable technological effort ${ }^{69}$ (In the report to Congress, Weinberger identified the United States strategic nuclear triad as in a state of dangerous obsolescence in comparison to the Soviets) in ensuring that its military forces remained ahead and more capable than its adversary. This included competition over the development of nuclear superiority in terms of numbers of nuclear missiles and counting the contributions of nuclear allies within NATO. The agreement of non-nuclear allies to the basing and accommodating temporarily of nuclear weapons systems was also factored into the equation.

The Reagan administration recognised that the balance of power of the West in both conventional and nuclear weapons had fallen behind the Soviet Union

\footnotetext{
${ }^{69}$ Caspar Weinberger, 'Department of Defence Annual Report to the Congress, 1985, http://osdhistory.defense.gov/docsreports.html (accessed 17 November 2011) 6
} 
during the 1970s and acknowledged the task of ensuring the power and preservation of American state. "They (the American people) recognized that we must regain the strength of our armed forces and restore the military balance so essential for deterrence."70

In terms of realism and Morgenthau's third principle of political realism, NATO shared common interests with the United States in the vital task of protecting their existence from the Soviet Union. The United States was firmly committed to Europe as the most likely potential theatre of nuclear war but at the same time was keenly aware of other threats required monitoring. Using the language of interest defined as power, NATO was a useful vehicle for the US to pursue its national interest and the national interests of other NATO nations were concurrently served. The confrontation on the Korean Peninsula in the 1950s was evidence that not only the Soviet threat needed countering but that other communist regimes such as China also had to be factored into the global equation of balancing power. United States policy therefore, was influenced by its role as the global leader, which is acknowledged in this quote "The United States needed to reassume a leadership role recognized by our allies, friends, and our foes and potential enemies." 71 In terms of the balance of power and the most crucial alliance was NATO, which underpinned the strategic rivalry with the Warsaw Pact and provided the reason for the United States to maintain a large expeditionary military equipped with nuclear weapons. Part of keeping the balance of power in

${ }^{70}$ Caspar Weinberger, 'Department of Defence Annual Report to the Congress 3 71 Ibid, 3. 
place meant control of resources, including nuclear weapons systems and the flexibility to use them.

The Nuclear Issue in the United States

Nuclear power production and nuclear weapons were an integral part of American life both from sustaining the standard of living and contributing to economic development. For example, in 1986 the United States nuclear domestic electricity generation comprised $15.5 \%$ of its national electricity product ${ }^{72}$ As well as maintaining its position as the nuclear superpower, the United States was encumbered with the task of maintaining a group of Western democratic states as allies to balance against the Eastern Bloc. In contrast the Soviet Union could maintain its power over the Warsaw Pact states more directly through economic ties and the imposition of membership of the communist system reinforced by the deployment of the Soviet military. The task of the United States was more challenging. Liberal democratic values of Western allies including elections and the right to protest by pressure groups within nations required a degree of management by the US to ensure ongoing commitment to the NATO alliance. The US had a leading role in maintaining the NATO coalition by virtue of its power and the regular relationship management occurred as NATO nations changed policies and governments as subtle accommodations and education were required. The rise of green party politics provided an added focus on environmental issues. The

\footnotetext{
72 LL Bennet and R. Skjoeldebrand, "Pages from the Past, nuclear power redux," International Atomic Energy Agency Bulletin, 50-20,2009, ((1984) 2
} 
notion of preservation of Western alliances comprised a mixture of tolerance of different policies and changing governments balanced against and maintaining coherent NATO strategic objectives. With the Presidency of Ronald Reagan the previous period of détente had changed with the negotiation of the Strategic Arms Limitations Talks (SALT). The nuclear balance started to tilt in favour of the United States and it could not afford any softening of position by allies in this competition for nuclear supremacy. Negotiating nuclear weapons reductions from a position of strength made sense from a realist point of view because of the definition of power to serve the national interest.

The Soviet Union had invaded Afghanistan in 1979 and this expansionist behaviour in a vulnerable part of the world was threatening to the Western alliance because the Soviet strategy increased the number of regions where the two blocs could engage in proxy wars. Aligned with this was the focus of the United States in the Pacific: to maintain an environment of acceptance of a potential United States military presence and to allow flexibility in options for dealing with potential aggression. Considerable diplomatic and security effort was devoted to the objective of maintaining acceptance and naturally allies with like-minded security concerns namely those members of NATO as well as enabling allies such as the Philippines, South Korea and Japan merited the most attention. Realism on the subject to the primacy of the survival of a state makes this focus the rational choice. When military resources are finite it is logical to locate them where they have the greatest utility and flexibility, and this fits with Morgenthau's second principle of a rational thought process leading to policy decisions. In the context of securing alliance partners in strategically significant areas, the location of United 
States allies and their port facilities was rational. The reason for interest in Asia was because China's and Russia's influence needed containment and the disposition of United States forces in South Korea, the Philippines, Japan and Hawaii provided a tangible reminder American of power.

The South Pacific

Into this mix came the distant allies of Australia and New Zealand who geographically are located in what was generally perceived by the United States as a more benign part of the world. Still further off the radar were the Pacific Island microstates whose importance since the end of the Pacific campaign in World War Two had diminished. Yet their recent independence and their economic fragility made them potential targets for Soviet influence. In the 1980s although Gorbachev signalled a new message in his Vladivostok speech where he highlighted the growing importance of the Pacific and his intention that the Soviet Union remained an Asia-Pacific power. He added the intentions of expanding its power and relationships with new nations and repairing relations with former foes. ${ }^{73}$ Another factor to be considered when measuring Soviet power in the Pacific were bases such as Cam Ran Bay in Viet Nam, from where the increasingly capable Soviet Navy could interdict and threaten the United States Pacific Fleet's regional activities. The Soviet Union had increased its naval presence globally and of the four fleets the largest was based in Cam Rah Bay. This fleet had grown from 50 to 85 surface

73 Coit D. Blacker, "The USSR in Asia in 1989 recasting relationships," Asian Survey, A Survey of Asia in 1989, 30, 1, (1990), 1-12. 
combatants which was a significant force in the region. ${ }^{74}$ The Soviet Union in the northern Pacific had sufficient military power to concern the United States and its allies. Assistant Secretary for East Asian and Pacific Affairs from the State Department Paul Wolfowitz expressed United States concerns as follows: “ But with the steady growth of Soviet military forces and that increasing and alarming tendency of the Soviets to use that force either directly themselves, as in Afghanistan, or indirectly, as in Kampuchea, Ethiopia, Chad or elsewhere, we emerged form our Vietnam experience with renewed determination, restored confidence and a heightened sense of realism." 75 To summarise the United States was occupied globally with a range of security concerns; the prime one was shared by the NATO partners in the European theatre, the second was the necessity to balance China on the Korean peninsula and underpinning this was the need to protect the of freedom of military movement which in turn protected US trade routes, economy and national interest. The least significant region was the "Pacific Area"76, which the ANZUS treaty covered. From a realist analysis the balance of power was difficult to achieve as national interest was defined broadly with the United States global interests ranging from Europe to Asia.

Soviet Aspirations in the Pacific

To quantify the Soviet influence in the South Pacific it is necessary first to understand why the United States and other ANZUS members were concerned. Soviet interest in the region was primarily focussed on economic activity in

\footnotetext{
74 Thakur, In Defence of New Zealand, Foreign Policy Choices in the Nuclear Age, 76 , 75“ANZUS vital to Asian Stability," United States Information Service, 5

${ }^{76}$ ANZUS Treaty, preamble, "comprehensive system of regional security in the Pacific Area"
} 
particular fishing. The Soviet Union sought shore facilities from various Pacific Island countries to sustain its fishing fleet and an arrangement was concluded with New Zealand which was announced in the Pacific Island Forum, that should New Zealand grant port facilities the Soviet Union would refrain from pursuing this request with other Pacific Island states. The reason for this compromise could be two-fold, the New Zealand national interest was better served by providing the port facilities as the economic advantages of dealing with the Soviet fleet had spinoff for trade, the Soviet Union was New Zealand's fifth or sixth largest trading partner and in particular the second largest importer of butter. ${ }^{77}$ The market for dairy products was important to New Zealand because of the British decision to curtail access to that market.

Secondly New Zealand was better positioned to provide a security over-watch and monitoring of Soviet activities while leveraging off through its alliance relationship with the United States and indirectly assisting with containment of the Soviets. By limiting the fishing fleet port activities to New Zealand, the United States national interest was also served and burden sharing of alliance responsibilities achieved in that New Zealand was contributing to the maintenance of regional security. Another interpretation could be the simple economic benefit for New Zealand, which directly fits with the realist view of pursuing national interest through a foreign policy choice relating to Morgenthau's third principle. The challenge for New Zealand was to maintain its security interests with the United States through ANZUS but at the same time ensure the nation's economic

\footnotetext{
77 Paul Dibb, "Soviet Strategy towards Australia and New Zealand and the South West Pacific," Australian Outlook, 39, 2 (n.d.) 73
} 
interests based on trade. The tension arose when a major trading partner such as the Soviet Union was at the same time an adversary through the security relationship with the United States. Small states manoeuvre between these two conflicting poles in order to protect their national interest ${ }^{78}$.

The purpose of the Soviet Union's intentions in the South Pacific are identified by Thakur ${ }^{79}$ was countering the United States presence in Micronesia, supporting New Caledonia independence, supporting SPNFZ, supporting New Zealand anti-nuclear policy and promoting the Soviet policy goals of political presence and economic cooperation. In analysing these objectives from a realist perspective the purpose was to constrain the United States power and flexibility through opportunistic use of regional issues to irritate with minimal cost, Exploiting existing points of tension which involved three allies, France, Australia and New Zealand was a clever and inexpensive way to promote Soviet influence by countering the United States.

In realist terms the Soviet goal is simply to undermine United States power in the South Pacific region and create opportunities and relationships for future development. The Soviet Union through small measures, presented itself as an alternative source of power to the United States should small states in the region wish to obtain assistance ${ }^{80}$ not provided by their usual friend. For the United States the challenge in balancing all of the small states in the Pacific was to provide enough aid and assistance to maintain the relationship without becoming

\footnotetext{
${ }^{78}$ Handel, Weak States and the International System, (London: F. Cass, 2981) 190.

${ }^{79}$ Dorrance, Thakur, Wanandi, Vasey, Pflatgraff, In Defence of New Zealand Foreign Policy Choices in the Nuclear Age, 53

${ }^{80}$ Handel, Weak States and the International System, 190.
} 
decisively engaged.

\section{Nuclear Non-Proliferation}

The United States position with regards to SPNFZ is another aspect that is useful to analyse because it provides insight into the decision making process on the nuclear issue. The treaty was not supported by the United States because of the potential implications for impinging the freedom of movement of the United States Navy's nuclear powered and armed ships. Although the treaty was drafted to carefully comply with international law of the sea, observing the principles of freedom of the high seas including rights of innocent passage, archipelagic rights of passage and transit passage through straits it was not immediately signed by the United States and the official reason given was: " The United States has completed its study and has decided that in view of our global security interests, and responsibilities we are not, under current circumstances, in a position to sign the protocols." 81 The decision to remain a non-signatory of the treaty was not unique to the United States with France and Great Britain also initially choosing this option and the fact that these two countries are also nuclear weapons owners and members of NATO is likely to have influenced this decision for similar reasons and also because of the power politics of alliance relationships. From a realist perspective any mechanism that provided a limitation on military activity would be an impediment to protecting national and collective security interests. The only

81 Glebbeek, “The South Pacific Nuclear Free Zone Treaty: A lost battle against the superpower?," 18. 
initial nuclear signatories were China and the Soviet Union, a stance that predictably was designed to counter the other Western NATO allies.

The United States was in the situation of simultaneously countering Soviet initiatives globally, while at the same time maintaining the ability to be able to influence China and North Korea and thirdly to be prepared to react to other Soviet initiatives in Africa, South America and North Asia including Afghanistan. In order to achieve these objectives, the support of allies in Asia and the Pacific under a collective security arrangement was important in order to ensure flexibility and freedom of movement and to balance power against communism. In 1984 the United States was in the middle of a "substantial effort to increase its conventional forces" 82 as declared by Wolfowitz, as part of the strategy to contain potential problems. New Zealand was an ally attempting to negotiate parts of an alliance to exclude nuclear weapons from its ports. The potential ramifications of the spread of the anti-nuclear contagion to allies such as Japan with its previously described sensitivity to all things nuclear, the Philippines and some Nordic countries was of concern to the United States because American interests could have been compromised if other states chose to ask the neither confirm nor deny question about the carriage of nuclear weapons. New Zealand was not the only ally to have discomfort in the nuclear aspect of alliance membership. In the next chapter the factors that led to the reaction of the United States to New Zealand's stance on nuclear issues and the measures chosen by the United States to send a message to the small state wishing to selectively interpret alliance obligations will be analysed

82 United States Information Service, "ANZUS vital to Asian Stability," 1. 
and once again realism applied to the analysis in order to better understand the decision-making process and the policy implications. 


\section{CHAPTER THREE: UNITED STATES POSTION ON ANZUS AND NEW ZEALAND'S RESPONSE}

In this chapter of the thesis the actions of the United States and New Zealand will be examined sequentially with a view to understanding the responses to each other's positions in terms of realism. In the case of the United States the boundaries of the new relationship with New Zealand will be analysed with attention to the following questions: why were economic sanctions not included in the government response? what can realism tell us about what tempered the response?; how did the United States response in reaction to New Zealand's stance to deny nuclear powered ships access to ports measure in terms of realism?; how did New Zealand react to the United States measures in terms of realism? These questions relate to the central question of the thesis and the analysis of these questions helps to support the argument that realism in an alliance relationship has limitations because of ethical and cultural aspects. The second part of this chapter will analyse the New Zealand response to the United States policy in terms of the passing of the anti-nuclear law, effects on the Defence Force, and how New Zealand international engagement refocused on Australia and international peacekeeping opportunities. Finally a brief reflection and analysis will be done on the place of an alliance such as ANZUS in practical terms and whether the difference over nuclear policy has affected the current and future relationship between the two states. 


\section{$\underline{\text { American Reaction }}$}

The United States response was swift to New Zealand's response on the rejection of the proposed visit of the USS Buchanan. It was announced that New Zealand's decision to refuse the Buchanan would mean the relationship between the two nations would change on various, but yet unspecified levels. The first step was to cancel the ANZUS Sea Eagle exercise ${ }^{83}$ while the State Department considered the full response coordinated throughout the various government departments. President Reagan's words on the matter did not definitively shut the door on future cooperation: "We deeply regret the decision by the New Zealand Government to deny port access to our ships... It is our deepest hope that New Zealand will restore the traditional cooperation that has existed between our two countries." 84 The refusal by New Zealand to allow the visit after the United States had gone to considerable effort to propose an acceptable ship as well as the high level military negotiation that had occurred prior to the proposal of the USS Buchanan surprised the United States.

Despite the measured language of President Reagan, the United States Ambassador delivered a clear message to New Zealand about its alliance responsibilities: " The decision by New Zealand to deny port access to a U.S combatant vessel which we had proposed to send here-in keeping with that policy (neither confirming nor denying the presence of nuclear weapons)—clearly represented a departure from the position of all post-World War II governments of New Zealand. This includes the second and third Labour Governments. That fact is

\footnotetext{
83 Anthony Hubbard and Bernard Lagan, “America retaliates," The Dominion, February 6, 1985, 1. 84 Monroe Browne, "An Address by the Hon. Monroe Browne, American Ambassador to New Zealand to the Wellington Lions' Club," 5.
} 
plain and indisputable. No other ally of the United States has ever precluded port access by challenging the neither-confirm-nor-deny policy." 85 The strength of the language left no doubt that the national interest of the United States was involved and that New Zealand posed an impediment to the strategy of global deterrence of communism and this was not acceptable. The language from the quote above emphasises that the Lange Labour Government had taken an action different from all predecessors regardless of their political persuasion. The refusal of the ship had crossed a line for the United States and the language signalled that New Zealand had taken an action not tolerable from an ally.

From the point of view of the United States the appreciation of the decision by New Zealand was a simple choice of belonging to the collective security alliance and taking up the inherent responsibilities or choosing to not participate in the alliance. There is mentioned in the writing of Hoadley ${ }^{86}$ and others ${ }^{87}$ to allow Buchanan access to New Zealand. Although there is no evidence in official records of events that an understanding had been informally reached between the two governments, this is logical to assume because senior defence officials had visited Hawaii in preparation for the request for the visit by Buchanan. The Americans therefore had an expectation that the carefully chosen ship visit would be acceptable to the Lange government. This is a reasonable supposition to make,

\footnotetext{
85 Monroe Browne, "An Address by the Hon. Monroe Browne, American Ambassador to New Zealand to the Wellington Lions' Club,"1.

${ }^{86}$ Hoadley, 'New Zealand United States Relations, friends no longer allies', 44.

87 James Rolfe, Defending New Zealand, A Study of Structures, Processes and Relationships,
} (Wellington, Institute of Policy Studies, Victoria University, The Printing Press, 1993) 94 
given the sensitivity of the issue and the willingness of officials to find a compromise.

In 1984 the ANZUS communiqué 88 issued at the end of the meeting made reference to continuing expectations of the signatories and the following statement was made: “ Access by allied aircraft and ships to the airfields and ports of the ANZUS members was reaffirmed as essential to the continuing effectiveness of the alliance." This position is further reflected in Department of Defense policy: "Our alliances were being subjected to new strains, as expanding Soviet military power required greater defense efforts by all members to restore the military balance." 89 The implications of denying port access had been clearly and variously signalled to New Zealand. From a realist perspective the response by the United States was rational, clearly articulated prior to allow New Zealand time for a rational thought process as could be expected in Morgenthau's second and third principles. These emphasise the cost benefit analysis necessity in making a foreign policy decision and the primacy of the national interest.

No economic sanctions?

The United States chose not to impose economic sanctions, which was a most vulnerable area where the most effective impact of power could have been exercised. France demonstrated the effectiveness of economic sanctions previously in 1986 when the French Government successfully pressured for the release of the two agents imprisoned over the sinking of the Rainbow Warrior in

\footnotetext{
88 "Australian Foreign Affairs Record”, Vol 55, No 7, Jul 1984, 686.

${ }^{89}$ Weinberger,"Department of Defence Annual Report to the Congress", 1985, 4.
} 
Auckland harbour. This incident where one member of the crew was killed by the bomb was the first incident of terrorism on New Zealand soil. The fact that the United States did not follow the same path speaks to its prestige as a powerful state and Morgenthau identifies this as an example of a having "retreated from exposed positions without suffering a loss in prestige." 90 To expand this concept in terms of classical realism the United States because of the great differential in power with New Zealand, could have acted quite differently and exerted its power to make an example of New Zealand to other American allies whose nuclear policy was similar to New Zealand's in that it was less central to their national interest. Prime Minister Lange recognised this fact in his words on the potential impact of economic sanctions that the United States: " might, if it had chosen, have damaged New Zealand's economic interests as easily as you might flick a caterpillar off your sleeve." 91 But the temptation to act more severely was avoided, despite nearly half of the Senate voting for retaliatory measures ${ }^{92}$ and therefore the restraint exercised by the United States contributes to its "lasting foundation of national power and prestige." ${ }^{93}$ A calculation of the cost benefit analysis of taking a more punitive approach is likely to have been done by the United States again using realism theory to evaluate the response.

This response is interpreted as partially fitting with realist theory but there are other factors at play here, which do not fit with realism in that ethical, cultural and moral ties with New Zealand historically played a role in the restraint shown

\footnotetext{
90 Morgenthau, Politics Among Nations The Struggle for Power and Peace, 79.

${ }^{91}$ McCraw,"New Zealand's foreign Policy Under National and Labour Governments 15.

92 NZPA Reuters, "ANZUS runs Hot," Evening Post, January 1, 1985,

93 Morgenthau, Politics Among Nations, The Struggle for Power and Peace, 79.
} 
by the large power. The United States could have easily chosen a more extreme reaction and from the emotional language used to describe the betrayal a more realist reaction could have been expected. Classical realism embraces the idea of a chaotic world with self-interest and survival as the raisons d'être for decisionmaking. Realist theory does not fit with the United States reaction because apart from the prestige aspect of power, a truly realist reaction to New Zealand's action in not accepting alliance duties would have been to cut all links because the United States did not have long term financial, economic or even political need for any time of alliance with New Zealand because of its small size and geographic irrelevance to what was going on with the Soviet Union in Europe. The New Zealand nuclear position was a distraction, which took focus away from the main issue of dealing with the Warsaw Pact. The United States had no need for any security relationship with a fair weather ally. A classical realist response would have been to cut any contact until the nuclear policy stance was reversed. So the question must be asked why did the United States leave the door open for a future relationship with New Zealand? This is not logical from a realist point of view. Something stopped the United States from acting in a coldly logical way and makes realism not apply to this alliance relationship. Was it apathy in that the political machine did not get around to enacting harsher legislation? This is disproved by the fact that Congress debated the issue for many years. Republicans supported the passing of the Broomfield Bill intended to disadvantage New Zealand by removal from the Foreign Assistance Act and Arms Export Control Act. This legislation would have damaged New Zealand interests further and has appeal from realist analysis. However the Democrats led by Solarz opposed further action 
and the issue was eventually dropped ${ }^{94}$ for reasons that are obscure and involve congressional procedure.

The conclusion that can be drawn from the lack of further legislative procedure was that the American government did not support any further action. The reasons for the less punitive response can be found in a mixture of emotional and cultural reasons. New Zealand United States had a habitual relationship that contained too much positive legacy, both countries had been always been on the same side in both World Wars and other conflicts; their paths towards nationhood were similar; the cultural links were strong namely both were English speaking, independent democracies and shared similar economic policies. Both countries also had intangible links that like cultures provide and where people with shared values have difficulty rejecting, and in the democratic tradition some American citizens supported the New Zealand anti-nuclear position as is evidence in a telegram received from United States citizen; “Dear Mr. Prime Minister: As an American, I can only say that we are not worthy of your trust. Don't allow U.S. nuclear weapons in N.Z. If you must placate U.S politicians accept nuclear powered ships. But not weapons.... It's not your conflict! Don't get blown up too."950r was it some appreciation of a longer term gain which although as yet undefined might have served United States interest in the future.

94 Hoadley, 'New Zealand United States Relations, friends no longer allies' 75-83.

95 “Letter of support offers PM a hug," The Dominion, February 6, 1985, 1 
Realism and the United States Response

Morgenthau's six principles of political realism were not followed in the decision of the United States to call the ANZUS alliance into abeyance. The first principle of separating fact from emotion does not apply because emotion played a role in the decision-making process and eventually the emotion between the Republicans and Democrats was spent and the issue became less relevant. The second principle of a rational thought process leading to foreign policy decisions, which minimise risk and maximise benefit was followed by the United States. There was risk to the United States of other nations following New Zealand's action the New Zealand example although this was partially mitigated because New Zealand agreed not to proselytise its nuclear policy.

The United States national interest was not served by allowing a state to defy alliance security goals at a time when the build up of conventional and nuclear military assets was occurring as the Reagan administration ${ }^{96}$ sought to step up pressure on the Warsaw Pact. The United States followed a rational thought process in deciding the degree of policy leeway that it accepted in an ally and then when this boundary had been crossed which the refusal of the USS Buchanan represented, a clearly signalled action was taken and ANZUS put into abeyance. This situation informs us of the necessity for clear communication between allies concerning sensitive issues and that there are limits to choices made within alliance constructs.

96 John Mearsheimer, The Tragedy of Great Power Politics, (New York: W.W Norton, 2001), 227. 
The fourth principle of political realism expresses the value of prudence and weighing the consequences of political action was observed by the United States. Despite New Zealand passing into legislation the Arms Control and Disarmament Act which in essence laid out a series of criteria that forbad the presence of nuclear powered or armed ships, the United States did not impose economic sanctions and continued to leave the way open for future negotiation. The United States risked to a certain extent its credibility as a large power by allowing New Zealand a relatively unscathed escape from its alliance obligations. The message sent to its main adversary the Soviet Union was that New Zealand's status as an ally was terminated and the Soviets predictably offered condemnation of the United States action, but made it clear New Zealand was welcome on the other side. Evidence of the Soviet Union's policy to counter the United States can be found in comments made on that the United States response "marked the culmination of a vicious antiNew Zealand campaign which has been mounted by the Reagan Administration." 97 Further evidence of Morgenthau's fourth principle of political realism; the weighing of the consequences of political action can be found in the United States limited response to New Zealand. The United States may have decided that the consequences for its alliances and relationships with other nations may have been negatively impacted if it had treated New Zealand more harshly. Thakur provides evidence of this thinking in Secretary of State Shultz's appreciation that economic sanctions could turn New Zealand into an enemy ${ }^{98}$. It is interesting to speculate on the international reaction by other states should this have occurred and it is highly

\footnotetext{
97Thakur, "Creation of a Nuclear-Free New Zealand Myth: Brinksmanship without a Brink," 919. 98 Ibid, 924.
} 
likely that other states particularly those closely linked to New Zealand such as the United Kingdom and Australia, other Commonwealth states and like-minded European allies would have protested if economic sanctions were imposed.

The influence of norms

In democratic society there is an expectation of behaviour of states towards each other and the notion of the society of states observing international norms. In referring to norms the definition of a standard of appropriate behaviour for actors of a given identity ${ }^{99}$ will be used. In this circumstance the power differential between the United States and New Zealand had implications for the appropriateness of behaviour, as also did the shared identity of liberal states. Membership of the society of international states also implies a notion of conformity to the evaluative relationship, as described by Finnemore and Sikkink as the relationship between states and state peers. ${ }^{100}$ This relationship between allies means that there was an expectation of appropriate behaviour. Morgenthau is in line with this concept and he describes the necessity for a powerful state to act with prestige and he says that the two measures of a state's power are power are its reputation for unchallengeable power and its reputation for selfrestraint. ${ }^{101}$ The United States was conscious of not only its obligations as a superpower but of the effect of too harsh treatment on small states exercising sovereign rights. In a truly realist equation the United States does not need the

\footnotetext{
${ }^{99}$ Martha Finnemore and Kathryn Sikkink"Norm dynamics and political change", International Organization, 52, 4, (1998) 887-915. 100 Ibid, 803.

${ }^{101}$ Morgenthau, Politics among Nations, The Struggle for Power and Peace, 77.
} 
support of others in terms of military power but it does require the support in terms of political capital and economic trade. The reputation of the United States could have suffered damage in the democratic world should it have acted more punitively. The link between rational behaviour in realist theory and norms is the evaluation of cost benefit analysis.

The United States as the leader of democratic Western nations has to work on maintaining consensus while the Soviet Union did not. This difference in roles places limitations on the nature of realism in a democratic state context. The other side of the reaction that must be considered is the likely reaction of the Soviet Union, which already had made clear its support of any anti-American actions and is likely to have made further advances towards New Zealand. A small state that is ostracised from its traditional partners is more likely to form an alliance with those who it can, as strength of small states as identified by Ingebritsen, is that they can manoeuvre and change trading partners quickly ${ }^{102}$. To summarise in the United States response there is a mixture of adherence to the some of Morgenthau's principles of political realism and in some areas the purity of a realist response based on rational decision-making does not apply and instead is influenced by cultural and historic ties.

\footnotetext{
102 Christine Ingebritsen, Iver Neumann, Sieglinde Gstohl, Jessica Beyer, Small States in International Relations, (Seattle: University of Washington Press, 2006), 176.
} 
New Zealand's Response to United States Action

New Zealand's reaction to the United States response was multilayered as the consequences of the anti-nuclear stance took effect. One consistent theme in the rhetoric was that of denial that the ANZUS alliance was in abeyance and there are consistent examples of the New Zealand government stating that New Zealand continued to observe ANZUS obligations but not in the hosting of nuclear ships. Prime Minister Lange's initial reply: “ The cancellation of the Anzus Sea Eagle exercise does not mean the Anzus Treaty is threatened." "So far as New Zealand is concerned, we remain ready and willing to contribute our full share to the ANZUS alliance." ${ }^{103}$ Another aspect was the genuine concern of the impact of trade sanctions and reassurance was sought early on how exactly the United States would enact the layers of possible punishment. Prime Minister Lange spelt out the implications of trade sanctions using language that demonstrated his understanding of the great difference in power and size of the two states. A few years later in his address at Yale he stated "The lesson is plain. In the end it proved impossible for a small country to maintain a security alliance with a nuclear power on any terms other than those set by the nuclear power." 104 In this statement the Prime Minister denies the realist interpretation that the more powerful state has the advantage of pursuing its national interest over the smaller alliance member. EOnce fears of trade sanctions were alleviated, informal pressure was placed on

\footnotetext{
103 ANZUS Communique, Press Statement, Prime Minister Lange, August 121986.

104 'The security alliance is a dead letter," extracts from Prime Minister Lange's Yale Speech, The Evening Post, 27 April 1989.
} 
New Zealand to reverse or soften the anti-nuclear stance. The language of the United States Ambassador who was closely linked to President Reagan was perceived as meddling in the politics of an independent state and instead of provoking debate and rational consideration, the opposite effect was produced where New Zealanders felt affronted by any attempts to change the policy of the democratically elected government and a determination to weather the storm of opprobrium and insist on sovereign rights to self-determination prevailed. Frank O'Flynn said, “ The foreign policy of a New Zealand Labour government will be made in Wellington, not in Washington." This statement was made in response to the distribution by the United States Embassy in Wellington, of documents from the State Department on ANZUS. The appropriateness of the action by the Ambassador in the lead-up to an election campaign was seized upon as interference.

The awareness of the moral significance of political action, Morgenthau's fourth principle of political realism was certainly not impacting on New Zealand policy making. This principle in this context requires the consideration of the survival of the state as the underpinning basis for decision-making and the careful weighing of consequences of actions. Morgenthau specifically contrasts the different levels of behaviour of the individual versus the state and the necessity of the state to maintain a longer term view and focus on survival: “... the state has no right to let its moral disapprobation of the infringement of liberty get in the way of successful political action." 105 The influence of emotion and the sense of the small

105 Morgenthau, Politics Among Nations, 10. 
nation standing up to the insensitive and rigid demands of the super power are evident and in Morgenthau's language prudence and the weighing of consequences of a course of action were absent or misjudged.

There was a strong element of national pride by New Zealand in making this stance against the United States. The previous experience by the same Government with France, where economic pressure was exerted by a threat to withdraw support for New Zealand dairy products to the European Union ${ }^{106}$ had worked. Economic pressure by France forced the government to release the French agent caught, tried and imprisoned over the bombing and causing a death, of the Rainbow Warrior in Auckland harbour. For New Zealand, this incident was a sharp reminder of the effectiveness of threatened trade sanctions by a large power. The intensity of the nationalism was such that anti-nuclear legislation was passed in the form of the Nuclear Free Zone, Disarmament and Arms Control Act. The sequence of events in the assurance by the United States that no trade sanctions would be imposed, which happened early in crisis and the later enactment of the New Zealand Nuclear Free Zone, Disarmament and Arms Control Act of law which was passed in June $1987^{107}$ are interesting in the cause and effect ramifications. It is interesting to speculate on whether New Zealand would have gone down the legislative path if national interest in terms of trade had not been taken out of the equation. If the threat of economic reprisal had remained in play, New Zealand would have been more vulnerable and therefore more susceptible to the power of the United States. The influence of the international focus also is a factor in the way

\footnotetext{
106 MacKay, "Nuclear Testing: New Zealand and France in the International Court of Justice”, 1867. 107 Tow, William T "The Anzus Dispute: Testing U.S. Extended Deterrence in Alliance Politics." Political Science Quarterly, 104,1, (1989), 129.
} 
in which the anti-nuclear issue played out between both nations. Prime Minister Lange eloquently stated the case for New Zealand's position in the Oxford union debate in March 1985 where he stated that there was no moral case for nuclear weapons. ${ }^{108}$ His power as a speaker and champion of the small state received generous coverage internationally. The effect of the international spotlight on the resolution of New Zealand to stand its ground added to the nationalism around the determination to remain anti-nuclear. However most New Zealanders did not wish to be out of a military alliance with the United States, but also did not want nuclear ships in New Zealand ports. ${ }^{109}$

Focus on the Pacific

Once the dust had settled New Zealand had to refocus its security policy and a new White Paper ${ }^{110}$ was produced with the importance of Australia clearly spelt out in the changed security situation. New Zealand had to redefine its security interest although the ANZUS treaty relationship was referred to Prime Minister Lange stated: "I believe we are seeing a new willingness to accept that security cannot be guaranteed solely by military means." 111 A small nation does not cast itself adrift, having experienced the comfort of an alliance with a large power. The attitude of Australia has been deliberately omitted from this thesis but it must be

\footnotetext{
108 “Oxford Union Debate," last modified December 22,2011 http://www.youtube.com/watch?v=0eHTziiFVx0.

109 Thakur, “The Last Bang before a Total Ban: French Nuclear Testing in the Pacific,” 934.

110 New Zealand Government. Defence of New Zealand, Review of Defence Policy,( Wellington: V.R. Ward, Government Printer, 1987)

111“"The security alliance is a dead letter," Evening Post, ‘April 27, 1989,
} 
considered briefly in relation to the cooling of United States - New Zealand military relations. Australia has always been significant strategically for New Zealand because of its geographic proximity and cultural affinity. ${ }^{112}$ New Zealand could not simply substitute Australia for the United States because the dynamic of the triangular relationship had been broken, leaving the United States and Australia as allies. From Australia's point of view a comparison of the cost benefit analysis of the value of the security relationships clearly weighs in favour of the United States, although strategic circumstances demand some continuing degree of security engagement because of some overlapping areas of interest namely the south pacific. Australia was placed in the position of needing both but the United States relationship clearly contained more advantages. This allowed Australia some leverage in its relationship with New Zealand who was in a more dependent position and needed to deepen its links.

\section{Military Engagement}

New Zealand had benefitted from its military relationship with the United States in terms of access to equipment through reliable and streamlined processes gained by those nations with special status ${ }^{113}$. Once this had disappeared New Zealand's national interest in terms of its ability to defend itself was at risk because there was no guarantee of access to spare parts and upgrades on the previously favourable terms. The majority of New Zealand Defence Force major equipment had been purchased from the United States, PC Orion maritime patrol aircraft,

\footnotetext{
112 Defence Review 1983,12

113 Hoadley, New Zealand United States Relations, friends no longer allies, 70.
} 
C130 transport aircraft, Sioux and Iroquois helicopters, M113 armoured personnel carriers. A significant exception was the Leander frigates of British origin. This meant that new equipment sources had to be found and the evolution of the closer defence relationship with Australia occurred. Through this relationship New Zealand purchased equipment in common with Australia such as the Steyr rifles and ANZAC frigates.

Another area where a new defence partner was needed was in the participation in major exercises. New Zealand was excluded from joint AustralianUnited States exercises and subsequently Australia was burdened with the request for separate exercises with New Zealand; the holding of separate exercises incurred a financial implication and a cost benefit analysis from the Australian point of view made the decision obvious. Simple substitution was not an answer with New Zealand in the needy position of requesting crumbs off the Australian table. New Zealand governments also took the opportunity to contribute to multinational peacekeeping operations ${ }^{114}$, mainly under the auspices of the United Nations. As well as keeping New Zealand Defence Force personnel in the Middle East in both the Sinai and the United Nations mission, it also sent forces to Somalia, Bosnia, Bougainville, East Timor, Iraq, Solomon Islands, Sudan and Afghanistan. This commitment to internationalism went some way to filling the gap in terms of training experience with a large professional left by the abeyance of the ANZUS alliance. Exercises with the British Armed Forces continued but the nuclear ship policy placed a constraint on this relationship for the New Zealand Defence Force.

\footnotetext{
${ }^{114}$ Hoadley, New Zealand United States Relations, friends no longer allies, 50.
} 
The United Nations and other peacekeeping commitments were mostly land focussed with the occasional Air Force and Navy deployments such as the deployment of a frigate to the Persian Gulf and the deployment of Hercules aircraft to the Gulf War and Somalia. The response to the loss of the wider opportunities to operate with the United States has been to interact with other militaries in peacekeeping operations.

The exception to this is Afghanistan and since 9/11 the US has worked with the New Zealand Defence Force on a more routine and sustained basis within the operational theatre. The state of the New Zealand/ United States relationship on security matters has improved as a result of New Zealand's commitment to the war on terrorism. Secretary of State Clinton's visit to New Zealand and the signing of the Wellington Declaration in November $2010^{115}$ signalled a change in the relationship. The text acknowledged New Zealand's continuing commitment to multi-lateralism and a new focus: "The United States-New Zealand strategic partnership is to have two fundamental elements: a new focus on practical cooperation in the Pacific region; and enhanced political and subject-matter dialogue-including regular Foreign Minister's meetings and political-military discussions." 116 The Wellington Declaration is part of a deliberate United States refocus on the Asia-Pacific region. As articulated by the Secretary of State, the importance of the recommitment to Asia-Pacific: " One of the most important tasks of American statecraft over the next decade will therefore be to lock in a

\footnotetext{
115 “Full Text of he Wellington Declaration,"last modified December 182011 http://www.stuff.co.nz/national/politics/4309206/Full-text-of-the-Wellington-Declaration 116 Ibid.
} 
substantially increased investment-diplomatic, economic, strategic and otherwise in the Asia-Pacific region."117

In summary, analysis of the United States approach to the questioning by New Zealand of nuclear ship visits as part of ANZUS obligations shows that realism applied to reasoning leading to the United States policy decision. This is because the United States global interests required the flexibility to deploy nuclear weapons secretively for the purpose of withholding this information from its Cold War adversary the Soviet Union. Poor communication between the United States and New Zealand on the differing national interests meant that firstly the United States did not understand their ally's perspective on nuclear weapons and secondly the Lange Labour Government did not appreciate the immutability of policy around nuclear weapons to the United States global strategy. The limits of realism in the alliance relationship are found in the fact that the United States did not impose trade sanctions on New Zealand; the use of this power is likely to have been effective. New Zealand adapted to the loss of the security relationship, as a small state does by refocusing on the South Pacific and Australia. Finally the norms of acceptable international behaviour influenced the behaviour of the United States towards New Zealand for the pragmatic reasons of firstly not wanting to create an enemy, and secondly to behave in the prestigious manner of a superpower. 


\section{Chapter Four: Conclusions}

This chapter is focussed on summarising how realism adds to understanding the relationship between New Zealand and the United States over the nuclear issue and whether realism provides any new insights into the relationship between the two countries. Realism provides a useful framework to examine the relationship between two countries of quite disparate size and therefore power in terms of the ability to influence in the economic, military and political spheres.

There are five significant findings in this thesis, relevant to Morgenthau's six principles of political realism. These are: firstly that the decision making of the United States and New Zealand over nuclear policy issues used realism in that both states were focussed on national interests. Secondly diverging national interests in an alliance relationship, exacerbated by poor communication, can exert so much pressure that the alliance, as is seen with ANZUS, becomes defunct. Thirdly, that in the case study covered by this thesis, there are limitations in applying realism to the ANZUS alliance because of the strong, shared ethical and cultural aspects of the relationship between the United States and New Zealand. Fourthly that the norms of international behaviour can accommodate realist theory because of the influence of international reputation and obligation underpinned by the realist theory of rational consideration of long term effects. Finally linkages between states evolve according to circumstances and in New Zealand's case continued 
engagement in the international community and the shared cultural ideals provided the grounds for revitalising a different security relationship.

Morgenthau's six principles of political realism have been used to measure the ways in which both the United States and New Zealand approached their ability to influence international perceptions on nuclear politics. Time and circumstances as described in the second part of Chapter One had a defining objective for the United States, namely that of survival. This fundamental consideration of national interest drove the United States down a path of decision making that reflected many of Morgenthau's principles of realism and this course of action can be explained as a logical and coherent decision making process. For all states in the international system the fundamental principle guiding political decision-making was the realist precept of survival. During the Cold War states chose between strategies of alignment or neutrality especially in Europe where the power of Soviet Union and its bloc made the survival of European states the main objective. The importance of nuclear weapons in the balance of power between the two Cold War sides was an essential force multiplier. Tolerance for deviation from the NATO and western alliance principles and objectives was low for the reason that an alliance of democratic countries provided was much more difficult to manage than the Warsaw Pact. The United States as the leader of the alliance in terms of power and influence needed the coherence of the NATO alliance as well as the support of the nations outside of the alliance in other geographic regions to guarantee security.

Into this context came a traditional ally, New Zealand with a differing perception of the nuclear threat because of its political, strategic and geographical 
environment as explained previously. The main points of Chapter One are that there was not one reason for the development of anti-nuclear policy in New Zealand but the synthesis of a variety of factors: environmental concerns, centred on nuclear testing; geographic isolation; growing independence and nationalism coupled with a role in the South Pacific region; a strand of anti-Americanism and frustration at being able to gain acknowledgement of a voice in the international system. The reasons for the development of the anti-nuclear sentiment have been analysed and the conclusion drawn is that a combination of factors ranging from alternative views on the benefits of collective security to the solidifying of an independent foreign policy and national security voice produced in New Zealand a clearer perception of its own national interest which happened to be at odds with its major ally.

The American position by contrast was engaged with the global problem of communism with a focus on Europe and NATO as the most likely theatre of conflict. Additionally Asia was a security concern because of China and North Korea as well as the Soviet eastern coast and bases with reach into the Pacific. In the 1980s President Reagan was building up nuclear and conventional forces the United States managed a disparate set of allies in order to balance against the Warsaw Pact while ensuring the ability to manoeuvre and respond to Soviet or its proxies activities throughout the world. In realist language the United States policy was to gain an exponentially larger and more sophisticated base of military power to guarantee survival and power over the Soviet Union. Gorbachev had signalled his intentions to increase the Soviet focus on the Pacific region and it was in the national interest of the United States to counter this proposed expansion. Nuclear 
weapons and nuclear powered ships constituted an essential aspect of this strategy. A weakening of the network of western alliances used to contain Soviet power was not palatable to the United States because of the potential that other allied states may have decided to negotiate their treaties to exclude nuclear weapons. This is not to say that global events turned on New Zealand's nuclear policy decision but risking any dilution of power was not in the United States national interest.

Applying realism to this alliance relationship between New Zealand and the United States within ANZUS makes the process of the policy choice of the United States to declare the alliance in abeyance, fit with the criteria of classical realism theory. Evidence of Morgenthau's realism can be found in the cool rationality behind the decision to terminate New Zealand's membership of ANZUS, the consequences of which had been signalled early to New Zealand because of the potential effect on the global balance of power and a recognition by the United States that the national interests of both states did not align on the nuclear issue and that there were consequences of this divergence. But the United States moderated its action to cauterise the wound but without severing the limb. This nuanced approach is where realism fails to provide an explanation because the decision to limit the punishment of New Zealand to military and intelligence cooperation, itself invoking Morgenthau's prudence, raises the question of why. Rationally the United States did not need New Zealand economically or militarily. Furthermore, and Australia provided an already existing alternative for the United States to engage in the region because of the close geographic locations to New Zealand. The only disadvantage in vesting interest uniquely in Australia was the 
absence of the cultural engagement New Zealand provided with some South Pacific Island states. So it is my proposition that realism does not explain the United States behaviour and that there are limits to realism in terms of alliance relationships where cultural ties, with their links to emotional sensibilities play an undefined and unpredictable role in decision making despite the clear logic that rationalism demands. Human links and past shared experiences such as alliances during World Wars as well as the strength of common cultural backgrounds work to undermine to a sufficient point to undo the rational calculations of a truly realist policy.

Both New Zealand and the United States had reasons, which can be attributed to realism, for belonging to the ANZUS treaty. To summarise these, New Zealand sought a replacement for the United Kingdom following the military withdrawal of the British from the region and the United States fitted the bill. Also there was the need to form an alliance with a large power featured strongly in the psyche of a young country. The threat of communism and the presence of the Soviet Union and China provided motivation to support this proposal and the advantages of allying with the United States and seeking commitment to the region was a rational decision. At the same time as New Zealand developed its independence the security environment of the South Pacific became a central concern of the government's foreign policy. With the growing integration of New Zealand into the South Pacific region which started in 1914 as the importance of the role of the United Kingdom slowly diminished, a new role as the champion of smaller states evolved. In terms of realism these small newly independent states sought some assurances of security and the advancement of their national interest 
through partnership with New Zealand. This paradoxically has parallels in New Zealand's objectives in forming an alliance with the United States, although no military alliances with South Pacific countries existed, political mechanisms such as the South Pacific Forum provided the vehicle for dialogue.

From the viewpoint of the United States, entering into an alliance with Australia and New Zealand after World War Two was not initially attractive but as the Cold War intensified the benefits of containing and denying Soviet room to manoeuvre, optimising options for global deployment and sharing the burden for maintaining small Pacific states support were recognised. The timing of the New Zealand government's decision to query the obligations of the ANZUS alliance was unfortunate because of Reagan's policy to build up conventional and nuclear military power. A wavering ally was not welcome with the consequences of any anti-nuclear contagion spreading to other allies equally undesirable. National interest was at stake and it could be argued that global interest meaning the defeat of the Soviet bloc was also on the table. Realist power politics emphasises the basic requirement to face power with superior power in order to ensure survival. Nuclear weapons were a significant force multiplier for the Western alliance and while the democratic rights of antinuclear movements within nations, to protest were part of the political landscape, remaining part of the coalition was expected. Therefore the centrality of nuclear weapons and the necessity of keeping the location of those mobile weapons a secret were essential to maintaining superiority over the Soviet arsenal. Nuclear weapons were an essential element of realist theory during the Cold War. 
The divergence of national interest threatened the survival of ANZUS and as New Zealand's threat perception of its involvement in the Cold War changed it seemed reasonable that the option of negotiating the treaty and accepting only partial responsibilities seemed valid. Both countries were applying realist principles to ensure their survival but there was no convergence of approaches. Realism appears to be a theory that applies to alliances only when national interests are in alignment. When a state cannot compromise or fit its national interest into the collective interests of an alliance, the alliance becomes a burden.

\section{$\underline{\text { Future Impacts }}$}

The difference of opinion between the United States and New Zealand over nuclear policy occurred twenty-seven years ago and despite the passing of the Nuclear Free Zone, Disarmament and Arms Control Act into law both countries have worked in international forums together and have frequently acted with similar interests in the international arena. So the question must be asked what difference has the placing into abeyance of ANZUS had on the various spheres of contact. Both states have retained similar interests in terms of democratic values, both have prospered economically and have participated in the world economy without the special but status imparted by a free trade agreement. In the security sphere, as New Zealand has deployed its military in United Nation and coalition missions there has been minimal contact but in the deployment of New Zealand Defence Force personnel to Afghanistan the contact between both militaries has been more substantial. It could be argued that New Zealand has played its cards 
carefully without retreating from its position on the issue of conflicting nuclear policy. The result has been an improved overall relationship through the benefits of active engagement with the United States on the war against terror. Realism again provides an insight into what has drawn both states closer together: the convergence of national interests in response to the common threat of Al Qaeda and terrorism. In Afghanistan the United States has partners from inside and outside of NATO and despite the difficulties in managing such a large and diverse coalition, traditional partners have mainly remained engaged in the war against terrorism although some states' domestic constituencies have withdrawn or modified the nature of their deployments.

\section{Future Research}

The third actor in the ANZUS partnership has for the most part been left out of the analysis because of limitations of space. But examining the relationship between the United States and Australia through the lens of realism is a potential area of further research. The different policy response of Australia where the antinuclear sentiment of parts of the population and government was reconciled with the maintenance of an even closer defence relationship with the United States would be worthy of researching as a companion to the New Zealand story. A comparison of the similarities in the strategic environment and role in the South Pacific with the differences in regional aspirations and in the degree of military and economic power could reveal another dimension in understanding the application of realism to the relationship. This thesis has shown that classical 
realism as expounded by Morgenthau still has relevance today, in understanding the relationship between the United States and New Zealand over nuclear policy. Morgenthau's six principles have some enduring qualities that despite the passage of time apply to the relationship between states. The case study of the United States and New Zealand does show that realism has its limits when soft power factors such as culture and shared historical experiences influence the pure rational categorisation between friend and foe. Realism remains a relevant tool to examine relationships between states when divergent national interests play a role in unsettling a comfortable alliance relationship as was evident in the United States and New Zealand over the nuclear issue. 


\section{BIBLIOGRAPHY}

ANZUS communiqué, Press Statement, Prime Minister David Lange, August 12, 1968

Australian Foreign Affairs Record, Volume 55, Number 7, July 1984

Ayson, Robert "Towards a Nuclear Weapons Free World? New Zealand and the Quest for Global Nuclear Disarmament." International Journal Vol 55, no. 4 (Autumn 2000): 531-544.

Baker, Richard. The ANZUS States and Their Region, Regional Policies of Australia, New Zealand, United States, (Westport, Connecticut, Praeger Publishers, 1994).

Bennett, L.L and R. Skjoeldebrand. "Pages from the Past, nuclear power reduction.” International Atomic Energy Agency Bulletin Issue 50-20, no. 2009, 1984.

Bengt Danielsson. "Under a Cloud of Secrecy: The French Nuclear Tests in the South-eastern Pacific." Ambio Vol.13, no. No.5/6 (1984): 336-341.

Billington, James H "Realism and Vision in American 3," Foreign Affairs Vol 65, no. 3 (1986): 630-652. 
Blackler, Coit D “The USSR in Asia in 1989 recasting relationships.” Asian Survey, A Survey of Asia in 1989 Vol 30, No 1, no. 1 (January 1990): 1-12.

Branch James B. "The Waste Bin: Nuclear Waste Dumping and Storage in the Pacific." Ambio vol 13, no. No5/6, the South Pacific (1984): 327-330.

Browne, Monroe "An Address by the Hon. Monroe Browne, American Ambassador to New Zealand to the Wellington Lions' Club", April 2, 1985.

Carr, E.H. The Twenty Years Crisis. (New York: Palgrave, 2011).

Clinton, Hillary “America's Pacific Century - Foreign Policy”, n.d. http://www.foreignpolicy.com/articles/2011/10/11/americas_pacific_century

Corner, Mr Frank, Major General B.M. Poananga, Dr Kevin P. Clements, Diane Hunt. The Defence Question: a discussion paper. (Wellington, New Zealand: V.R. Ward, Government Printer, 1985).

“Defence Review 1983”. (P.D. Hasselberg, Government Printer, Wellington, New Zealand, 1983).

Dibb, Paul "Soviet Strategy towards Australia, New Zealand and the South-West Pacific." Australian Outlook 39, n o. 2 (n.d.): 69-76. 
Dominion, “Anzus: US spells out threat to Pacific”, Wellington, 24 July 1984.

Dorrance, John C, Ramesh Thakur, Jusuf Wanandi, L.R. Vasey, Robert L. Pflatzgraff, Jr. The South Pacific Emerging Security Issues and U.S. Policy. (Virginia: Brasseys (US) Inc, 1990).

Evening Post, "US expert warns not to sacrifice Anzus" Wellington, 4 Jan 1984.

Evening Post, "The security alliance is a dead letter," extracts from Prime Minister Lange’s Yale Speech, 27 April 1989.

Evening Post, “Anzus allows blunt dialogue with the US”, Wellington, June 20, 1984.

Evening Post, “ANZUS runs hot,” Wellington, January 1, 1985.

Finnemore, Martha and Kathryn Sikkink. "'Norm dynamics and political change', 5." International Organization, 52, no. 4 (1998): pp 887-915.

Finnemore, Martha, "Norm culture and world politics," International Organization, 50, March 1996, pp 325-341,

Finnemore, Martha National Interests in International Society (Cornell University Press, 1996, p.27. 
"Full text of the Wellington Declaration | Stuff.co.nz", n.d.

http://www.stuff.co.nz/national/politics/4309206/Full-text-of-the-Wellington-Declaration.

Glebbeek, Pieter. "The South Pacific Nuclear Free Zone Treaty: A lost battle against the superpower?" Working Paper Series 7, January 1990.

Glaser, Charles C Rational Theory of International Politics. (New Jersey: Princeton University Press, 2010).

Handel, Michael. Weak States and the International System:,(London, England; Totowa, N.J. : F. Cass, 1981).

Hoadley, Stephen New Zealand United States Relations, friends no longer allies. Wellington: (New Zealand Institute of International Affairs, 2000).

Hoadley, Stephen and Ruland Jurgen, Asia Security Reassessed. Singapore: Institute of South East Asia Studies, 2006.

Hubbard, Anthony “Admiral backs ANZUS.” The Dominion. Wellington, April 13, 1984. 
Hubbard, Anthony and Lagan Bernard. "America retaliates." The Dominion. Wellington, New Zealand, February 6, 1985.

Ingebritsen, Christine, Iver Neumann, Sieglinde Gstohl, and Jessica Beyer Edited by Small States in International Relations. Seattle: University of Washington Press, 2006.

Jones, Matthew, “A Decision Delayed: Britain's Withdrawal from South East Asia Reconsidered, 1961-68," English Historical Review, 117, (2002): 569-595

Kipnis, Kenneth, Diana T Myers edited by, “Political Realism and International Morality," (Boulder, Westview Press 1987).

Lagan Bernard, “Lange rebuffs Reagan,” The Dominion, Wellington 26 July 1984.

Langdon, Frank C. "Challenges to the United States in the South Pacific.” Pacific Affairs, University of British Colombia Vol 61, no. 1 (Spring 1988): 7-26.

Lange, Rt Hon, David, Prime Minister, “ANZUS Communiqué” Press Statement, 12 August 1986.

Long, Richard. "Labour faces debate on Anzus remit." The Dominion. Wellington, 26 April, 1983. 
Long, Richard. "Anzus threat denied”, The Dominion. Wellington, 28 June 1983.

Long, Richard, “Lange: 'Our role is diminished,' The Dominion, Wellington, 1984.

Long, Richard, “Embassy defends action on ANZUS, ” The Dominion, Wellington, 26 July 1984.

Mc Craw. David J, “New Zealand’s Foreign Policy Under National and Labour Governments: Variations on the 'Small State' Theme?" Pacific Affairs, University of British Colombia Vol 67, No. 1, no. 1994 (n.d.): pp 7-25.

Main, Victoria, "New Zealand nuclear stance pro-Russian”, The Dominion, Wellington, 22 May 1985.

MacKay, Don. "Nuclear Testing: New Zealand and France in the International Court of Justice", June 5, 1996.

Mearsheimer, John J. The Tragedy of Great Power Politics. (New York: W.W Norton and Company, 2001).

Mediansky, F.A. “ANZUS in Crisis Author.” The Australian Quarterly 57, no. No 1/2 (1985): pp 7-20. 
Molloy, Sean. “Truth, Power, Theory: Hans Morgenthau's Formulation of Realism.” Diplomacy and Statecraft 15, no. 1 (August 10, 2010): 1-34.

Morgenthau, Hans J. “'Great Debate': The National Interest of the United States.” American Political Science Review Vol 46, no. 4 (December 1952): 961-968.

Morgenthau, Hans J. Politics Among Nations, The Struggle for Power and Peace.

Fourth Edition. (New York: Alfred A. Knopf, 1968).

Morgenthau, Hans J "The Four Paradoxes of Nuclear Strategy.” American Political Science Review 58, no. 1 (March 1964): pp. 23-35.

Morgenthau, Hans J. “To intervene or not to intervene." Foreign Affairs, 1967, 92103.

Moses, Jonathon W and Torbjorn L. Knutsen. Ways of Knowing Competing Methodologies in Social Science and Political Research. (Hampshire: Palgrave Macmillan, 2007).

Neville, Hugh, "NZ weakens Pacific unity says Shultz" NZPA, The Dominion, 19 July 1985.

New Zealand Government. Defence of New Zealand, Review of Defence Policy. Wellington, New Zealand: V.R. Ward, Government Printer, 1987. 
New Zealand Government. The Defence of New Zealand 1991, A Policy Paper. Wellington, New Zealand: Government Print Ltd, 1991.

Norrish, Mr. M Secretary of Foreign Affairs. “ANZUS: Implications for the South Pacific and New Zealand”. Foreign Policy Speeches, No 3, 15 July 1983, June 9, 1983.

President of the United States. "National Security Strategy of the United States". The White House, 1987.

Pugh Michael, "Anzus on the Rocks Author(s):" The World Today 41, no. 4 (April 1985): 79-84.

Rafferty Kirsten, “An Institutionalist Reinterpretation of Cold War Alliance Systems: Insights for Alliance Theory." Canadian Journal of Political Science Vol 36, no. 2 (June 2003): 341-362.

Ratti, Luca "Post-Cold War NATO and International Relations Theory: The Case for Neo-Classical Realism." Journal of Transatlantic Studies 4, no. 1 (2006): 81-110.

Reiter, Dan. "Learning, Realism and Alliances: The Weight of the Shadow of the Past." World Politics Vol 46, no. 4 (July 1984): 490-526. 
Rolfe, James. Defending New Zealand, A Study of Structures, Processes and Relationships, , Victoria University, Wellington, The Printing Press, 1993.

“South Pacific Nuclear-Free Zone Treaty (Treaty of Rarotonga)”. Inventory of International Non-proliferation Organizations and Regimes, May 5, 2011.

Stuff.co.nz. "Full text of the Wellington Declaration |", November 4, 2010. http://www.stuff.co.nz/national/politics/4309206/Full-text-of-the-Wellington-Declaration.

Simes, Dimitri K “Gorbachev, a new foreign policy?” Foreign Affairs, Vol 65, no. 3 (n.d.). http/www.jstor.org/stable/20043077

Thakur. Ramesh “Creation of the Nuclear-Free New Zealand Myth: Brinksmanship without a Brink." Asian Survey Vol. 29, no. 10 (October 1989): 919-939.

Thakur. Ramesh In Defence of New Zealand, Foreign Policy Choices in the Nuclear Age. Boulder Colorado and London: Westview Press, 1984.

Thakur. Ramesh. “The Last Bang before a Total Ban: French Nuclear Testing in the Pacific." International Journal Vol. 51, No 3, Nuclear Politics (Summer 1996): 466486.

Tow, William T “The Anzus Dispute: Testing U.S. Extended Deterrence in Alliance Politics.” Political Science Quarterly Vol. 104, no. 1 (Spring 1989): pp 117-149. 
United States Information Service. "ANZUS vital to Asian Stability". Embassy of the United States, Wellington, June 26, 1984.

United States Information Service. "Transcript of Press Conference 33rd ANZUS Council Meeting, July 16-17, 1984, July 17, 1984.

VietnamWar.govt.nz http://www.vietnamwar.govt.nz/resources , accessed 22/12/11.

Weinberger, Caspar W. Secretary of Defense. "Annual Report to the Congress". US Government Printing Office, Washington DC, Fiscal Year 1985. /tmp/PreviewPasteboardItems/1985 DoD Annual Report PDF.

Waltz, Kenneth N, Theory of International Politics. Illinois: Waveland Press Inc, 1979. 